\title{
The South India Precambrian crust and shallow lithospheric mantle: Initial results from the India Deep Earth Imaging Experiment (INDEX)
}

\author{
S S Rai ${ }^{1, *}$, Kajaljyoti Borah ${ }^{1}$, Ritima Das ${ }^{1}$, Sandeep Gupta ${ }^{1}$, Shalivahan Srivastava ${ }^{2}$, \\ K S Prakasam ${ }^{1}$, K Sivaram ${ }^{1}$, Sudesh Kumar ${ }^{1}$ and Rishikesh Meena ${ }^{1}$ \\ ${ }^{1}$ CSIR - National Geophysical Research Institute, Hyderabad 500 007, India. \\ ${ }^{2}$ Department of Applied Geophysics, Indian School of Mines, Dhanbad, Jharkhand 826 004, India. \\ ${ }^{*}$ Corresponding author.e-mail: shyamsrai@gmail.com
}

We present here the most comprehensive study of the thickness and composition $(V p / V s$ ratio) of the South India Precambrian crust and the nature of shallower mantle inferred from analysis of teleseismic receiver functions from 70 broad-band seismic stations operated as a part of the India Deep Earth Imaging Experiment (INDEX). South India could be broadly divided into regions with thin crust (32-38 km) and thick crust $(38-54 \mathrm{~km})$. Thin crust domains include the East Dharwar Craton (EDC), Cuddapah basin and Madurai/Kerala Khondalite Block. The thicker crust domain includes the Western Dharwar Craton (WDC) and northern part of Southern Granulite Terrain. The WDC shows progressive increase in thickness from $38 \mathrm{~km}$ in north to $46-54 \mathrm{~km}$ in south, compared to an almost flat Moho beneath the EDC. Compositionally, most of the crustal domains are felsic to intermediate $(V p / V s \sim 1.69-1.75)$ except the mid Archean block in the southern WDC where it is mafic $(V p / V s>1.81)$. Considering erosion depth in the WDC, we argue for Himalaya like $\sim 70 \mathrm{~km}$ thick crust beneath it during the Archean. Variation in crustal thickness does not have a first-order influence on regional topography in South India and suggests significant role for the crustal composition. We also present evidence of mid-lithospheric low velocity at 85-100 km beneath South India.

\section{Introduction}

Most of our knowledge about the evolution of continents and their crust and mantle signature is restricted to terrains younger than $\sim 3.3$ Ga due to large scale thermal modifications prior to this age. Two prominent continental crust forming events at $\sim 3.3 \mathrm{Ga}$ and $2.7 \mathrm{Ga}$ have been reported during the Archean (de Wit et al. 1992; Rudnick 1995; Condie 2005; Hawkesworth and Kemp 2006; van Kranendonk 2011; Dhuime et al. 2012). It remains highly speculative about the process responsible for its evolution. It is widely accepted that plate-tectonic processes operated at least as far back as $2.7 \mathrm{Ga}$ (Calvert et al. 1995; White et al. 2003). Middle Archean terrains (3.6-3.0 Ga), however, lack most of the features associated with convergent plate boundaries and could possibly have evolved through melting of thick mafic crust (Davies 1992; de Wit 1998; Zegers and van Keken 2001; Nagel et al. 2012). Scientific opinion, however, remains divided on the process responsible for the formation and evolution of the early and middle Archean continental crust. In order to achieve comprehensive definition of the crust evolution process(es) during Precambrian and its modification

Keywords. Receiver function; crustal structure; lithosphere; craton; South India; Archean. 


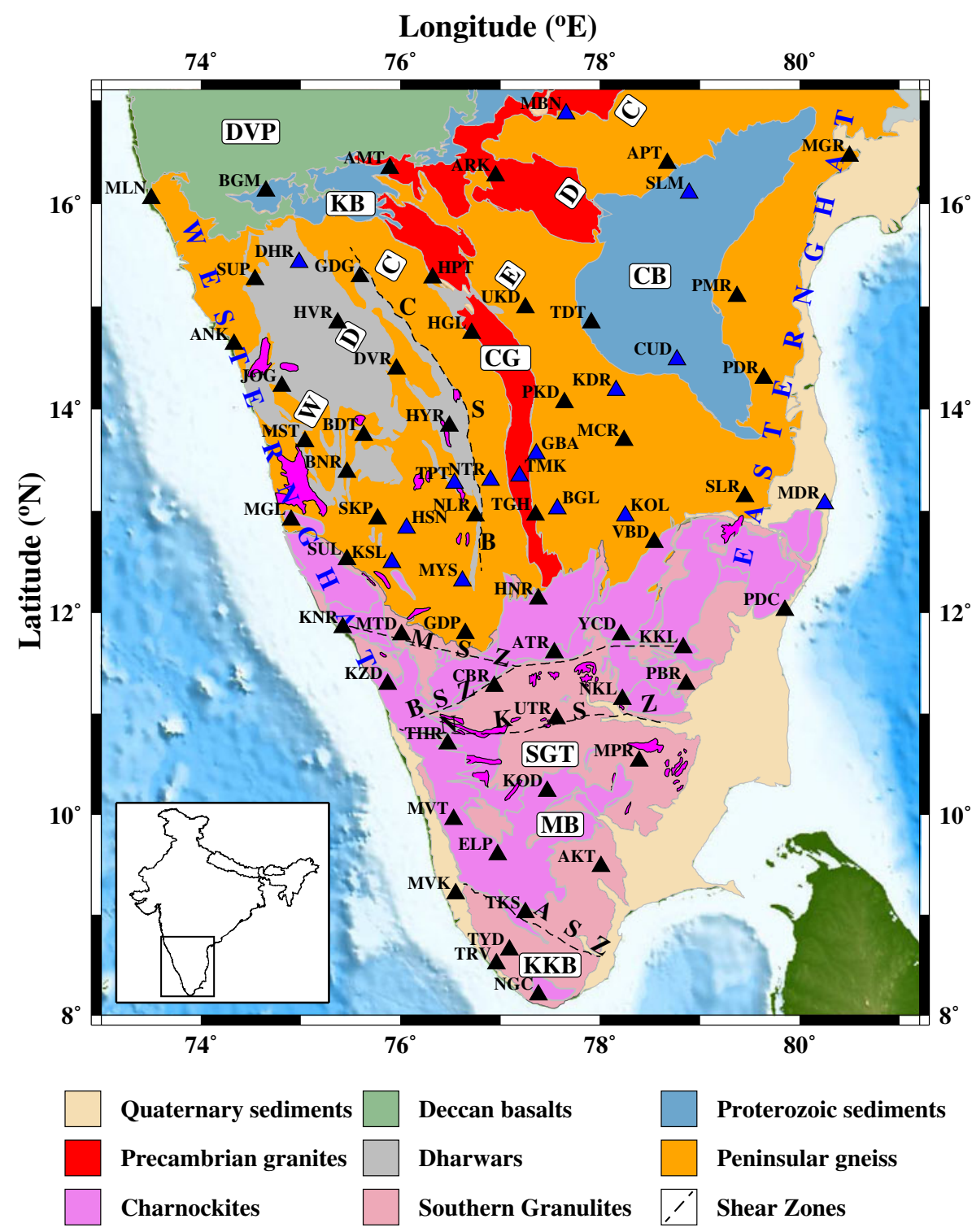

Figure 1. Tectonic map of South India Shield showing major geological terrains, viz., EDC - East Dharwar Craton, WDC West Dharwar Craton, SGT - Southern Granulite Terrain, DVP - Deccan Volcanic Province, CB - Cuddapah Basin, CG - Closepet Granite, CSB - Chitradurga Schist Belt, MSZ - Moyar Shear Zone, BSZ - Bhavani Shear Zone, NKSZ - Noyil Kaveri Shear Zone, ASZ - Achankovil Shear Zone, KB - Kaladgi Basin, BB - Bhima Basin, MB - Madurai Block, KKB - Kerala Khondalite Belt. The seismic stations used in the study are shown as black (2009-2012) and blue (1998-2002) triangles.

due to recent geodynamic activity, there is need for better constraining the structure and composition of the crust and mantle, and nature of the crust-mantle interaction in geological blocks with diverse ages.

To address above issues, we initiated a long term research project India Deep Earth Imaging Experiment (INDEX), supported by the Council of Scientific and Industrial Research (CSIR). The project aims at creating 3D seismic structure of the Indian crust and mantle to constrain the evolutionary mechanism along with establishing linkage with ore deposition and earthquake genesis in the region. In its first phase, the seismic imaging is attempted for South India at various scales using data from teleseismic waveforms recorded over 70 broad-band seismographs that operated in phases during 1998-2002 and 2009-2012 (figure 1).

\section{Project objectives}

\subsection{Origin and evolution of the Precambrian continental crust}

Present day continental crust with andesitic composition has evolved from differentiation of the oceanic crust that is basaltic in nature (Rudnick 
and Gao 2003; Hawkesworth and Kemp 2006). Identification and modelling of petrogenetic processes responsible for the transformation of a primitive basaltic crust to andesitic/felsic composition remains ambiguous. It is an unresolved problem related to the evolution of the continental crust through geologic time with a bearing on the mantle processes. Seismological wave velocities $(V p, V s)$ and their ratio have been extensively used to characterize different rock types in the crust (Christensen 1996). The velocity ratio varies over a wide range (1.65-1.85) depending on the quartz content in it: felsic rocks have lower value compared to more mafic one. A clear definition of composition of the crust and its age relationship can help in constraining the nature of source and modelling the evolution mechanism (Gao et al. 1998).

Apart from composition, the other significant parameter of crust is its thickness. One of the models of crustal evolution based on global compilation of seismological measurements suggests that the mean crustal thickness, except for young orogens, is proportional to its age, with ancient crust being the thickest (Meissner 1986; Jarchow and Thompson 1989). This led to the hypothesis that the crust is thickened by repeated episodes of basaltic underplating (Nelson 1991). We hope to answer the validity of the global model for crustal evolution with respect to South India.

\subsection{Nature of the deep mantle}

To model the process responsible for evolution of the Earth's mantle, one of the most important caveats is to understand the nature of internal layering and its spatial variability (Anderson 2006). This is best revealed in the seismic images of the deep Earth. Cold sinking oceanic slabs show as high seismic wave velocity regions while the low velocity features are suggestive of hotter mantle (van der Hilst 2004). Gathering detailed evidence of preserved deep high/low velocity signatures within the plates in the ancient cores of the continents ('shields'), is thus essential to our understanding of the early Earth. The continental cratonic regions are underlain by a thick high velocity zone to a depth of about $250 \mathrm{~km}$ and suggesting primary difference from the oceanic part. We propose to map the depth of cratonic root beneath parts of South India using these seismological data and also compare and contrast with similar terrains in other parts of the globe. Further, we attempt to examine the presence of shallow mantle discontinuities that might help in hypothesizing the geodynamic processes leading to or subsequent to cratonisation of South India.

The deeper features like transition zone from 410 to $600 \mathrm{~km}$ depth could now be easily mapped.
Interestingly, some of the recent tomographic images suggest presence of cold sinking slabs to a depth of $1000 \mathrm{~km}$ beneath the southern part of India (Replumaz et al. 2004). The paleoreconstructions show that seafloor spreading in the Neo-Tethys Ocean had ceased by Late Cretaceous, and that Tethyan lithosphere was being consumed along two subduction zones; one following the south Asian margin and the other, intra-oceanic, crossing the Neo-Tethys Ocean and fringing an Arabian margin still attached to East Africa. It is widely accepted that after all the Neo-Tethys lithosphere was consumed, India continued its northward drift, indenting into Asia for several hundred kilometers, and giving rise to the Himalayan orogen and the high topography of the Tibetan plateau (Besse and Courtillot 1988). As the subcontinent progressed along this collisional journey towards Asia, the subducting slabs detached from the surface continental plate and the subduction zones were overridden (Replumaz et al. 2004). The search for signatures of these slabs and their seismic properties can throw new light on the nature of interaction of oceanic slabs with the major Earth discontinuities, and can provide constraints on the convection models involving both thermal and chemical effects. This would also possibly answer the cause for the Indian Ocean geoid low (Spasojevic et al. 2010). This will be achieved by creating high resolution image of South India using these broad-band seismological measurements.

\section{Geological framework and crust structure of South India}

The South India Shield is an amalgamation of several crustal blocks formed by geodynamic processes operating from mid-Archean to Neo-Proterozoic time. The main geological provinces in southern India are shown in figure 1 . The Dharwar craton in the southern India is an Archean continental fragment with a continuously-exposed crustal section from low-grade gneisses and greenstone basins in north to granulites in the south. It comprises of three distinct lithological units: Peninsular gneisses of tonalite-trondhjemite-granodiorite (TTG) composition dated between 3.36 and 2.7 Ga (Taylor et al. 1984; Meen et al. 1992), volcano-sedimentary greenstone belt of two distinct ages 3.3-3.1 Ga and 3.2-2.7 Ga (Peucat et al. 1995) and the K-rich granitoids (e.g., N-S trending Closepet granite) of age 2.5-2.6 Ga. Based on the ages and lithologies, the craton is divided into the West Dharwar Craton (WDC) and the East Dharwar Craton (EDC) with Chitradurga Schist Belt (CSB) as the boundary (Naqvi and Rogers 1996). 
Table 1. Details of South India broad-band seismograph network stations, Moho depth (H), Vp/Vs ratio with bootstrap errors, Poisson's ratio $(\sigma)$ computed from $H-k$ analysis, number of receiver functions $\left(N_{R F}\right)$ used in the analysis.

\begin{tabular}{|c|c|c|c|c|c|c|c|c|}
\hline Stn. code & $\begin{array}{l}\text { Lat. } \\
\left({ }^{\circ} \mathrm{N}\right)\end{array}$ & $\begin{array}{c}\text { Long. } \\
\left({ }^{\circ} \mathrm{E}\right)\end{array}$ & $\begin{array}{l}\text { Elv. } \\
(\mathrm{m})\end{array}$ & Period of operation & $N_{R F}$ & $\begin{array}{c}H \\
(\mathrm{~km})\end{array}$ & $V p / V s$ & $\sigma$ \\
\hline \multicolumn{9}{|c|}{ East Dharwar Craton } \\
\hline $\mathrm{MBN}$ & 16.87 & 77.66 & 417 & 01/1999-07/2000 & 58 & $34.40 \pm 0.11$ & $1.754 \pm 0.004$ & 0.259 \\
\hline $\mathrm{AMT}$ & 16.34 & 75.89 & 542 & 02/2009-04/2010 & 54 & $35.80 \pm 0.22$ & $1.718 \pm 0.010$ & 0.244 \\
\hline ARK & 16.27 & 76.95 & 487 & 05/2009-09/2011 & 21 & $33.95 \pm 0.41$ & $1.760 \pm 0.018$ & 0.262 \\
\hline $\mathrm{APT}$ & 16.39 & 78.67 & 453 & 07/2009-08/2011 & 47 & $32.05 \pm 0.64$ & $1.800 \pm 0.019$ & 0.277 \\
\hline UKD & 14.99 & 77.25 & 474 & 07/2009-05/2011 & 15 & $33.70 \pm 1.16$ & $1.770 \pm 0.020$ & 0.266 \\
\hline PKD & 14.06 & 77.64 & 545 & 05/2009-05/2011 & 53 & $35.40 \pm 0.14$ & $1.758 \pm 0.005$ & 0.261 \\
\hline KDR & 14.18 & 78.16 & 453 & 07/2000-06/2001 & 7 & $40.05 \pm 2.33$ & $1.758 \pm 0.005$ & 0.261 \\
\hline MCR & 13.69 & 78.24 & 635 & 02/2009-01/2011 & 32 & $37.20 \pm 3.76$ & $1.720 \pm 0.097$ & 0.245 \\
\hline GBA & 13.56 & 77.36 & 681 & 09/1998-11/2001 & 91 & $35.00 \pm 0.14$ & $1.746 \pm 0.006$ & 0.256 \\
\hline BGL & 13.02 & 77.57 & 791 & 09/1998-09/2000 & 30 & $34.90 \pm 0.20$ & $1.758 \pm 0.007$ & 0.261 \\
\hline $\mathrm{KOL}$ & 12.95 & 78.25 & 803 & 01/2001-08/2001 & 9 & $33.80 \pm 0.47$ & $1.745 \pm 0.017$ & 0.256 \\
\hline SLR & 13.14 & 79.45 & 141 & 02/2009-01/2011 & 37 & $37.00 \pm 0.35$ & $1.732 \pm 0.006$ & 0.250 \\
\hline VBD & 12.96 & 78.54 & 382 & 02/2009-01/2011 & - & - & - & - \\
\hline \multicolumn{9}{|c|}{ Cuddapah Basin } \\
\hline SLM & 16.10 & 78.89 & 368 & 11/1998-06/2000 & 27 & $33.90 \pm 0.39$ & $1.772 \pm 0.015$ & 0.266 \\
\hline TDT & 14.84 & 77.91 & 276 & 03/2009-08/2011 & 9 & $35.90 \pm 0.89$ & $1.756 \pm 0.027$ & 0.260 \\
\hline CUD & 14.48 & 78.77 & 150 & 05/1999-08/2001 & 43 & $35.55 \pm 0.17$ & $1.740 \pm 0.009$ & 0.253 \\
\hline \multicolumn{9}{|c|}{ Closepet Granite } \\
\hline $\mathrm{HPT}$ & 15.28 & 76.32 & 538 & 02/2009-03/2010 & 27 & $36.00 \pm 0.49$ & $1.725 \pm 0.016$ & 0.247 \\
\hline HGL & 14.74 & 76.71 & 564 & 03/2011-08/2011 & 20 & $34.35 \pm 0.79$ & $1.800 \pm 0.026$ & 0.280 \\
\hline TMK & 13.34 & 77.19 & 842 & $07 / 2000-11 / 2001$ & 13 & $35.70 \pm 0.87$ & $1.770 \pm 0.021$ & 0.266 \\
\hline NTR & 13.30 & 76.90 & 712 & $11 / 2001-01 / 2002$ & 7 & $40.40 \pm 1.32$ & $1.762 \pm 0.035$ & 0.262 \\
\hline TGH & 12.96 & 77.35 & 807 & 04/2009-04/2010 & 43 & $36.90 \pm 0.29$ & $1.720 \pm 0.008$ & 0.245 \\
\hline \multicolumn{9}{|c|}{ Kaladgi Basin } \\
\hline BGM & 16.12 & 74.65 & 658 & 02/2009-08/2011 & 14 & $48.60 \pm 0.47$ & $1.720 \pm 0.011$ & 0.245 \\
\hline \multicolumn{9}{|c|}{ Western Dharwar Craton } \\
\hline SUP & 15.26 & 74.54 & 536 & 05/2009-03/2011 & 18 & $37.90 \pm 0.32$ & $1.768 \pm 0.013$ & 0.265 \\
\hline MST & 13.68 & 75.04 & 589 & 05/2009-03/2011 & 7 & $39.70 \pm 5.11$ & $1.728 \pm 0.009$ & 0.248 \\
\hline $\mathrm{BDT}$ & 13.74 & 75.63 & 637 & 02/2009-01/2011 & 15 & $37.95 \pm 0.26$ & $1.728 \pm 0.009$ & 0.248 \\
\hline BNR & 13.38 & 75.46 & 753 & 03/2011-08/2011 & 15 & $36.55 \pm 0.16$ & $1.718 \pm 0.008$ & 0.244 \\
\hline DHR & 15.43 & 74.98 & 679 & 08/2001-05/2002 & 7 & $44.30 \pm 8.36$ & $1.768 \pm 0.013$ & 0.265 \\
\hline GDG & 15.29 & 75.59 & 726 & 03/2011-08/2011 & 40 & $44.35 \pm 0.21$ & $1.732 \pm 0.008$ & 0.250 \\
\hline JOG & 14.22 & 74.81 & 497 & 03/2011-08/2011 & 17 & $44.50 \pm 0.44$ & $1.740 \pm 0.16$ & 0.253 \\
\hline HVR & 14.84 & 75.37 & 615 & 02/2009-03/2011 & 37 & $45.50 \pm 0.12$ & $1.720 \pm 0.020$ & 0.245 \\
\hline DVR & 14.39 & 75.96 & 614 & 05/2009-01/2011 & 64 & $37.95 \pm 2.39$ & $1.785 \pm 0.065$ & 0.271 \\
\hline HYR & 13.88 & 76.49 & 661 & 02/2009-03/2011 & 10 & $46.50 \pm 1.06$ & $1.728 \pm 0.009$ & 0.248 \\
\hline $\mathrm{TPT}$ & 13.27 & 76.54 & 785 & $07 / 2000-12 / 2001$ & 38 & $46.80 \pm 0.13$ & $1.732 \pm 0.003$ & 0.250 \\
\hline NLR & 12.95 & 76.75 & 789 & 02/2009-08/2011 & 20 & $46.05 \pm 5.93$ & $1.732 \pm 0.003$ & 0.250 \\
\hline SKP & 12.92 & 75.77 & 947 & 02/2009-01/2011 & 12 & $46.70 \pm 0.45$ & $1.830 \pm 0.019$ & 0.287 \\
\hline $\mathrm{HSN}$ & 12.83 & 76.06 & 792 & $07 / 2000-12 / 2001$ & 20 & $46.15 \pm 0.34$ & $1.755 \pm 0.008$ & 0.260 \\
\hline KSL & 12.49 & 75.91 & 796 & 06/2001-12/2001 & 13 & $53.60 \pm 2.11$ & $1.755 \pm 0.003$ & 0.260 \\
\hline SUL & 12.53 & 75.47 & 107 & 01/2011-08/2011 & 36 & $47.95 \pm 0.14$ & $1.810 \pm 0.008$ & 0.280 \\
\hline MYS & 12.31 & 76.62 & 697 & $12 / 2001-06 / 2002$ & 7 & $48.60 \pm 4.86$ & $1.830 \pm 0.050$ & 0.287 \\
\hline GDP & 11.79 & 76.65 & 843 & 03/2009-04/2010 & 16 & $49.35 \pm 5.51$ & $1.760 \pm 0.110$ & 0.262 \\
\hline \multicolumn{9}{|c|}{ Western Ghats } \\
\hline MLN & 16.05 & 73.50 & 52 & 02/2009-08/2011 & 11 & $41.85 \pm 0.56$ & $1.836 \pm 0.011$ & 0.289 \\
\hline ANK & 14.63 & 74.33 & 22 & 03/2011-08/2011 & 11 & $39.50 \pm 0.016$ & $1.740 \pm 0.016$ & 0.253 \\
\hline MGL & 12.91 & 74.90 & 99 & 02/2009-08/2011 & 21 & $40.95 \pm 0.25$ & $1.806 \pm 0.009$ & 0.279 \\
\hline KNR & 11.84 & 75.42 & 49 & 01/2009-01/2011 & 20 & $43.52 \pm 0.28$ & $1.810 \pm 0.013$ & 0.280 \\
\hline KZD & 11.29 & 75.87 & 39 & 04/2010-02/2012 & 12 & $43.20 \pm 0.55$ & $1.775 \pm 0.012$ & 0.268 \\
\hline
\end{tabular}


Table 1. (Continued.)

\begin{tabular}{|c|c|c|c|c|c|c|c|c|}
\hline Stn. code & $\begin{array}{l}\text { Lat. } \\
\left({ }^{\circ} \mathrm{N}\right)\end{array}$ & $\begin{array}{c}\text { Long. } \\
\left({ }^{\circ} \mathrm{E}\right)\end{array}$ & $\begin{array}{l}\text { Elv. } \\
(\mathrm{m})\end{array}$ & Period of operation & $N_{R F}$ & $\begin{array}{c}H \\
(\mathrm{~km})\end{array}$ & $V p / V s$ & $\sigma$ \\
\hline \multicolumn{9}{|c|}{ Southern Granulite Terrain } \\
\hline MTD & 11.78 & 76.01 & 542 & 02/2009-08/2011 & 8 & $50.30 \pm 0.79$ & $1.740 \pm 0.015$ & 0.253 \\
\hline CBR & 11.27 & 76.94 & 348 & $04 / 2010-05 / 2011$ & 24 & $46.20 \pm 0.45$ & $1.755 \pm 0.018$ & 0.260 \\
\hline HNR & 12.13 & 77.39 & 594 & 02/2011-04/2012 & 61 & $45.60 \pm 0.40$ & $1.774 \pm 0.009$ & 0.267 \\
\hline ATR & 11.60 & 77.54 & 280 & 05/2011-04/2012 & 5 & $47.20 \pm 1.90$ & $1.690 \pm 0.035$ & 0.230 \\
\hline YCD & 11.78 & 78.21 & 1374 & 02/2009-02/2011 & 14 & $46.50 \pm 2.69$ & $1.730 \pm 0.020$ & 0.249 \\
\hline NKL & 11.14 & 78.22 & 163 & $04 / 2010-05 / 2011$ & 26 & $45.50 \pm 0.48$ & $1.712 \pm 0.017$ & 0.241 \\
\hline PBR & 11.29 & 78.86 & 130 & 04/2010-04/2012 & 34 & $40.05 \pm 3.68$ & $1.730 \pm 0.020$ & 0.249 \\
\hline KKL & 11.65 & 78.83 & 155 & 02/2009-04/2010 & 21 & $38.75 \pm 0.29$ & $1.730 \pm 0.020$ & 0.249 \\
\hline UTR & 10.95 & 77.50 & 267 & 05/2011-04/2012 & 5 & $44.75 \pm 0.13$ & $1.742 \pm 0.012$ & 0.254 \\
\hline THR & 10.70 & 76.47 & 61 & 02/2011-04/2012 & 7 & $44.45 \pm 0.55$ & $1.716 \pm 0.012$ & 0.243 \\
\hline MPR & 10.53 & 78.40 & 212 & $01 / 2011-04 / 2012$ & 58 & $41.80 \pm 0.24$ & $1.690 \pm 0.012$ & 0.231 \\
\hline \multicolumn{9}{|c|}{ Madurai Block/Kerala Khondelite Block } \\
\hline $\mathrm{KOD}$ & 10.23 & 77.47 & 2335 & $04 / 2010-05 / 2011$ & 40 & $43.20 \pm 0.24$ & $1.748 \pm 0.006$ & 0.257 \\
\hline MVT & 09.95 & 76.53 & 151 & $02 / 2011-03 / 2012$ & 53 & $37.50 \pm 4.31$ & $1.760 \pm 0.076$ & 0.261 \\
\hline ELP & 09.60 & 76.97 & 1114 & 05/2011-03/2012 & 16 & $38.40 \pm 0.41$ & $1.765 \pm 0.012$ & 0.264 \\
\hline $\mathrm{AKT}$ & 09.48 & 78.01 & 98 & $01 / 2011-04 / 2012$ & - & - & - & - \\
\hline MVK & 09.21 & 76.56 & 14 & $01 / 2011-03 / 2012$ & 7 & $38.80 \pm 2.31$ & $1.710 \pm 0.030$ & 0.240 \\
\hline TKS & 09.02 & 77.25 & 215 & $01 / 2011-03 / 2012$ & 55 & $36.70 \pm 0.17$ & $1.770 \pm 0.002$ & 0.266 \\
\hline TYD & 08.65 & 77.09 & 153 & $05 / 2011-03 / 2012$ & 5 & $32.50 \pm 0.47$ & $1.745 \pm 0.032$ & 0.255 \\
\hline TRV & 08.51 & 76.96 & 64 & 05/2000-06/2002 & 4 & $35.20 \pm 0.33$ & $1.730 \pm 0.009$ & 0.250 \\
\hline NGC & 08.20 & 77.38 & 49 & $01 / 2011-03 / 2012$ & 43 & $34.40 \pm 0.05$ & $1.740 \pm 0.003$ & 0.253 \\
\hline \multicolumn{9}{|c|}{ Eastern Ghats } \\
\hline MGR & 16.46 & 80.50 & 32 & 05/2010-08/2011 & 21 & $47.10 \pm 0.32$ & $1.726 \pm 0.010$ & 0.247 \\
\hline PMR & 15.10 & 79.37 & 123 & 05/2009-08/2011 & 17 & $39.50 \pm 0.36$ & $1.760 \pm 0.015$ & 0.262 \\
\hline PDR & 14.30 & 79.64 & 77 & 02/2009-08/2011 & 18 & $29.50 \pm 0.27$ & $1.760 \pm 0.015$ & 0.262 \\
\hline MDR & 13.07 & 80.25 & 15 & $05 / 2000-12 / 2000$ & 8 & $38.80 \pm 2.14$ & $1.760 \pm 0.015$ & 0.262 \\
\hline $\mathrm{PDC}$ & 12.02 & 79.85 & 37 & $05 / 2009-01 / 2011$ & - & - & - & - \\
\hline
\end{tabular}

The WDC is made of $3.3-3.0$ Ga gneisses and greenstone with enclaves of $2.5 \mathrm{Ga}$ granite. Southern part of the WDC hosts $3.36 \mathrm{Ga}$ greenstone belts while the northern part constitutes the 2.6 Ga Dharwar Basins. The WDC shows increasing degree of metamorphism and exposes rocks from $3-5 \mathrm{~Kb}$ and $500^{\circ} \mathrm{C}$ (greenschist facies) in north (at $15^{\circ} \mathrm{N}$ ) to $8 \mathrm{~Kb}$ and $800^{\circ} \mathrm{C}$ (granulite facies) at $13^{\circ} \mathrm{N}$ in south corresponding to tectonic upliftment and erosion of $5 \mathrm{~km}$ in north to $\sim 20 \mathrm{~km}$ in south, respectively. The WDC in the north is covered by Proterozoic Kaladgi Basin (KB) and Bhima Basin (BB) and the Deccan volcanics (DVP). The western part of the WDC is bounded by the Western Ghats (WG), an escarpment formed during separation of India from Madagascar at $\sim 90 \mathrm{Ma}$. The EDC is dominated by late Archean (2.5-2.7 Ga) calc-alkaline complex of juvenile and anatectic granites, granodiorites and diorites (Drury et al. 1984; Bouhallier et al. 1995; Chadwick et al. 2000) and is also termed as Dharwar batholiths. The EDC is in thrusted contact with the Proterozoic Cuddapah Basin (CB) and the Eastern Ghat Granulite Terrain (EG).
The craton progressively transitions in south into Archean metamorphic terrain $(2.6 \mathrm{Ga})$, widely known as the Southern Granulite Terrain (SGT). The granulites are dissected by the well-mapped Moyar and Bhavani shear zones (MSZ/BSZ) in north and the Noyil-Kaveri shear zone (NKSZ) in south. The Pan-African terrain of southern India occur south of the NKSZ and are comprised of northern Madurai Block (MB) and southern Kerala Khondalite Belt (KKB) separated by NNWSSE Achankovil Shear Zone (ASZ) (figure 1). These two terrains, whilst they have both suffered similar granulite facies metamorphism at $\sim 600 \mathrm{Ma}$ (Raith et al. 1983, 1997; Drury et al. 1984), belong to two distinctly different protoliths distinguished by the existence in Kerala block, of extensive deposits of deep shale sequences overlying a possibly Archean basement, subsequently granulitized to khondalites.

Our present understanding of the nature of the crust beneath the South India shield is largely based on the seismic wave velocity derived from the modelling of wide angle reflection and refraction measurements along two profiles, surface 
wave and receiver function approach from a few broad-band seismograph locations. Using seismic reflection/refraction data across the WDC/EDC, Kaila and Krishna (1992) found Moho depth varying from $34 \mathrm{~km}$ in the east to $41 \mathrm{~km}$ in the west. Inversion of Rayleigh wave phase velocity in the eastern part of the shield suggests an average crustal thickness of $35 \mathrm{~km}$ (Mitra et al. 2006). Receiver function modelling studies from a few broad-band seismographs (Gaur and Priestley 1996; Rai et al. 2003; Sarkar et al. 2003; Gupta et al. 2003a, b; Jagadeesh and Rai 2008; Kiselev et al. 2008; Julia et al. 2009) suggest a felsic and transparent crust beneath the eastern part of the shield (EDC) in contrast with a layered crust beneath the western part (WDC). Also, eastern part of the shield is characterized by Moho at $\sim 35-38 \mathrm{~km}$ while the western and southern parts have Moho depth varying from $42-55 \mathrm{~km}$. They also found average $V p / V s$ ratio variation of 1.65-1.76 in South India. A lower Poisson's ratio (0.25-0.28) than that expected for a high-grade metamorphic terrain indicates a felsic to intermediate crust beneath the SGT (Gupta et al. 2003a). Receiver function modelling from two stations in the SGT shows crustal thickness and $V p / V s$ ratio variation of $43.5 \pm 0.7 \mathrm{~km}$ and $1.753 \pm 0.015$ for station KOD and $36.5 \pm 0.9 \mathrm{~km}$ and $1.722 \pm 0.017$ for station TRV that correspond to felsic to intermediate composition respectively (Rai et al. 2008). Modelling of gravity field study also shows Moho depth variation of 33-48 $\mathrm{km}$ in SGT with the maximum of $53 \mathrm{~km}$ beneath the Nilgiri hills (Kumar et al. 2011).

\section{Receiver function data analysis}

For the first time, adequate coverage of the broadband seismic stations (70 nos.) has been made to study the nature of Moho and average $V p / V s$ ratio, beneath the individual seismograph location in South India. Most of these stations (55 nos.) operated during 2009-2012; the other 15 are part of an earlier experiment during 1998-2002 (Gupta et al. 2003a, b). Those 55 stations were operated in two phases in leap-frog mode with at least 10 stations common to both the periods. Details of their location and other results are presented in table 1. Each station consists of Guralp CMG3T/3ESP sensor with flat response between $0.0083 / 0.025$ and $50 \mathrm{~Hz}$ and a Refraction Technology data logger. Data were continuously recorded at 20 samples/s. We used over 4000 three-component seismograms from earthquakes in the epicentral distance range $30^{\circ}-95^{\circ}$, and magnitude greater than 5.5 , with clear $P$-wave arrivals. These are used to model the crustal parameters following receiver function approach.

\subsection{Methodology}

When seismic waves strike an interface between two media, they are reflected and/or refracted following the Snell's law. Apart from refraction and reflection, $P$-to- $S$ conversion also takes place at the interface. In the case of plane interfaces in isotropic media, only conversions between $P$ - and $S V$-waves (polarized in the plane of refraction/reflection) occur, but for anisotropic media or dipping interfaces, $S H$-waves (polarized perpendicular to the plane of refraction/reflection) are also generated. Since $S$-waves propagate slower than $P$-waves, the converted phases arrive within the $P$-wave coda following the direct $P$-onset. The time difference
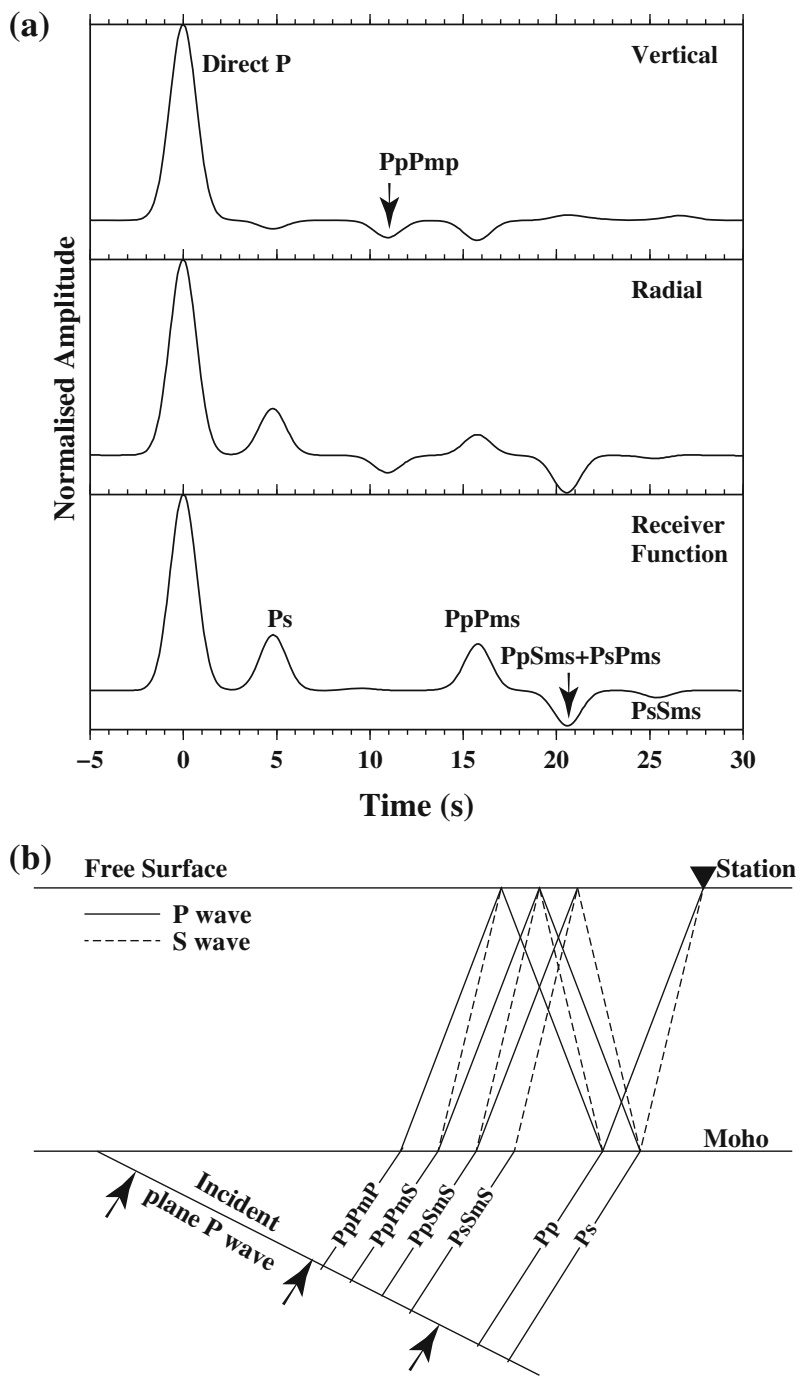

Figure 2. (a) Radial receiver function time series computed from deconvolution of vertical seismogram from the radial seismogram. (b) Ray diagram of different phases. 
between the onsets can be used to determine the depths where the conversions occurred. Receiver function analysis model the amplitude and time of $P$-to- $S$ converted phases $(P s)$ and reverberations associated with interfaces beneath the recording site. For events more than $30^{\circ}$ epicentral distance, $P$-waves are steeply incident and dominate the

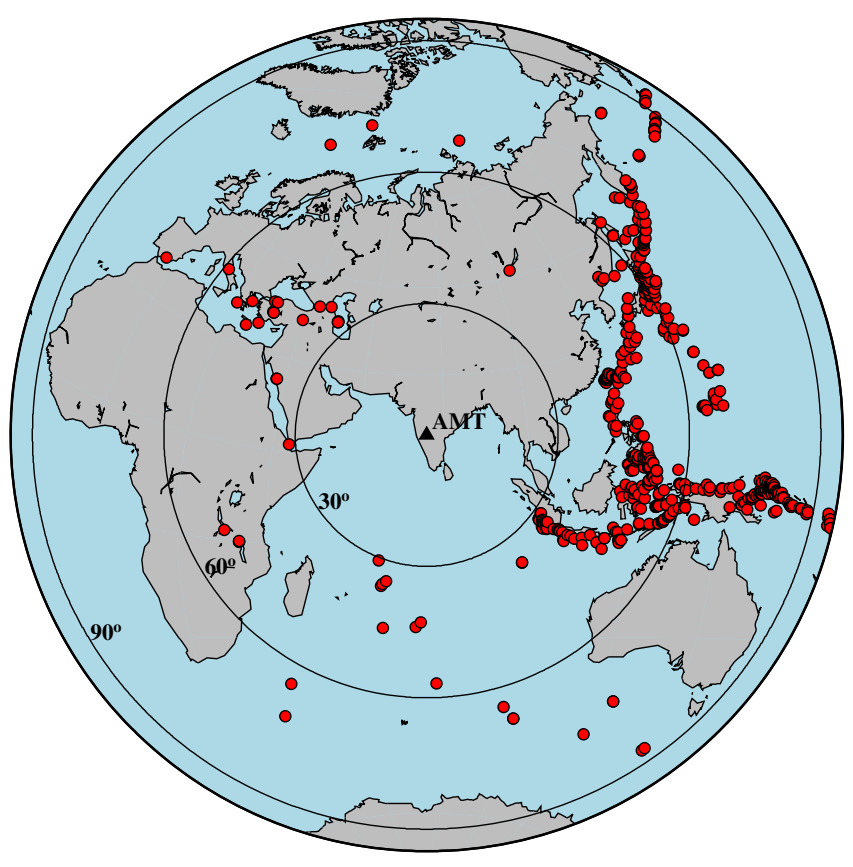

Figure 3. Epicenter locations of the earthquakes (red circles) of magnitude greater than 5.5, recorded by station AMT (black triangle). vertical component, whereas $P s$ are contained on the horizontal components of ground motion. The amplitude of the arrivals in a receiver function depends on the incidence angle of the impinging $P$-wave and size of the velocity contrasts generating the conversion $(P s)$ and multiples ( $P p P m s$, $P p S m s$, etc.). The arrival times of converted phase and multiples depend on the surface and the $P$ wave incidence angle and ray parameter. Figure 2 shows the phases that arrive at a seismic station as a result of interaction with a single crustal layer over a half space, and the corresponding radial receiver function obtained by deconvolving vertical component with the radial component. In the frequency domain, this can be written:

$$
H(\omega)=\frac{R(\omega)}{Z(\omega)}
$$

where $\omega$ is the angular frequency $2 \Pi f . Z(\omega)$ and $R(\omega)$ are the Fourier transforms of the vertical and radial seismograms. $H(\omega)$ is the Fourier transform of the receiver function.

We used earthquakes of magnitude greater than 5.5 from epicenter distance between $30^{\circ}$ and $95^{\circ}$ to avoid multiple arrivals in the direct $P$-wave occurring at distances less than $30^{\circ}$ caused due to triplication and also complication at distances greater than $95^{\circ}$ resulting from core mantle boundary. Due to geographical location, the data availability for stations is azimuthally skewed with most of the earthquakes from north to east directions. This is demonstrated in figure 3 showing earthquake distribution for a typical station AMT. Seismograms

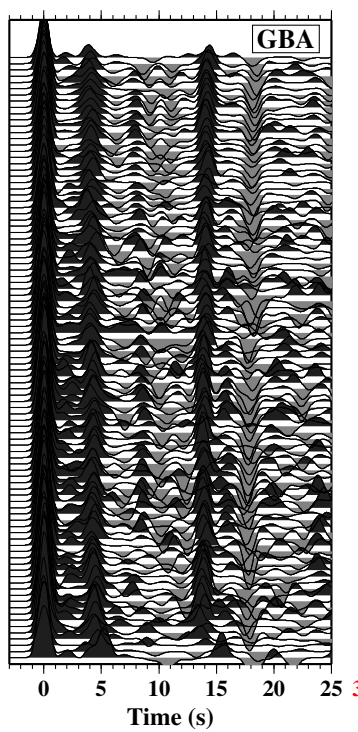

$\begin{array}{lllll}0 & 90 & 180 & 270 & 360\end{array}$

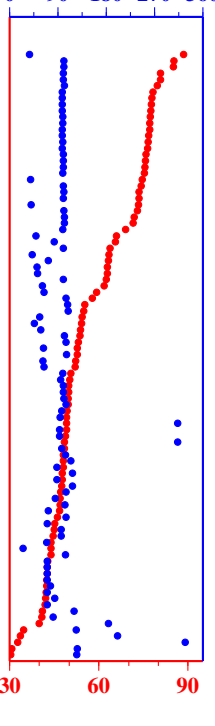



$\begin{array}{llllll}0 & 90 & 180 & 270 & 360\end{array}$

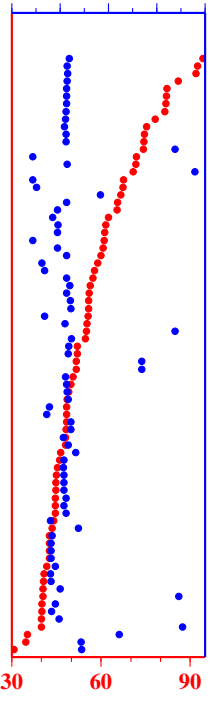

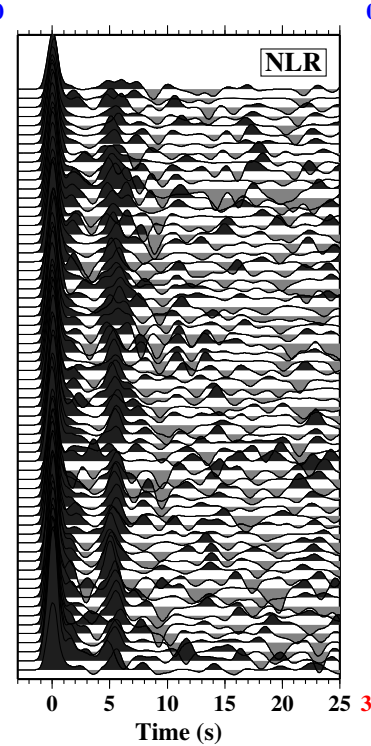

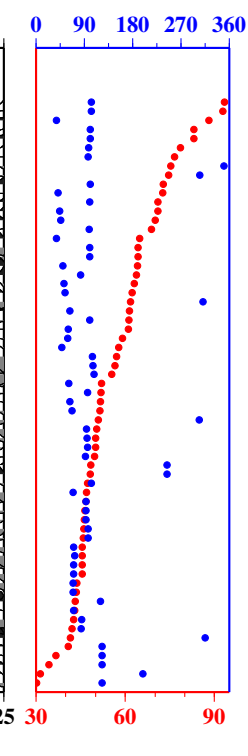

Figure 4. Quality of receiver functions (A, B or C) at three representative stations GBA, APT and NLR, respectively. Quality A refers to: clear $P$-to- $S$ conversion $(P s)$ and multiples $(P p P m s, P p S m s)$; B: clear Ps and PpPms or PpSms, and C: only clear $P s$. Red and blue circles denote the epicentral distance and backazimuth values for individual receiver function. 
corresponding to these events are checked visually and only those with clear $P$ arrival are filtered using Butterworth high pass filter with a corner frequency of $0.02 \mathrm{~Hz}$. The $P$ arrival on the seismogram is marked with respect to the IASP91 velocity model (Kennett and Engdahl 1991) using TaupTool-kit (Crotwell et al. 1999). We used $150 \mathrm{~s}$ of the waveform (30 s prior to $P$ arrival and $120 \mathrm{~s}$ post length) and removed the mean (DC effect) and trend (tilt in the base line) from the seismograms. Horizontal components (north/south and east/west) are rotated into the great circle path to obtain radial (perpendicular to vertical and directed towards the source) and transverse components (perpendicular to both vertical and radial components). Finally, vertical component is deconvolved from both radial and transverse components using iterative time domain deconvolution with 200 iterations (Ligorria and Ammon 1999). In this method, at first, the vertical component is cross-correlated with the radial component to estimate the lag of the first and largest spike in the receiver function (the direct $P$ phase). Then the convolution of the current estimate of the receiver function with the vertical component seismogram is subtracted from the radial component seismogram, and the procedure is repeated to estimate other spike lags and amplitudes. With each additional spike in the receiver function, the misfit between the vertical and receiver function convolution and the radial component seismogram is reduced, and the iteration halts when the reduction in misfit with additional spikes becomes insignificant.

A Gaussian filter of width (Gw) 1.6 is used during the deconvolution to select the most appropriate frequency band $(<0.8 \mathrm{~Hz})$. We preferred Gaussian width of 1.6 since the receiver function for higher Gaussian width had more noise, while those with lower Gaussian width are smoother. For detailed analysis, we selected over 1600 receiver functions with more than $80 \%$ waveform fit, from an initial nearly 4000 receiver functions. A closer

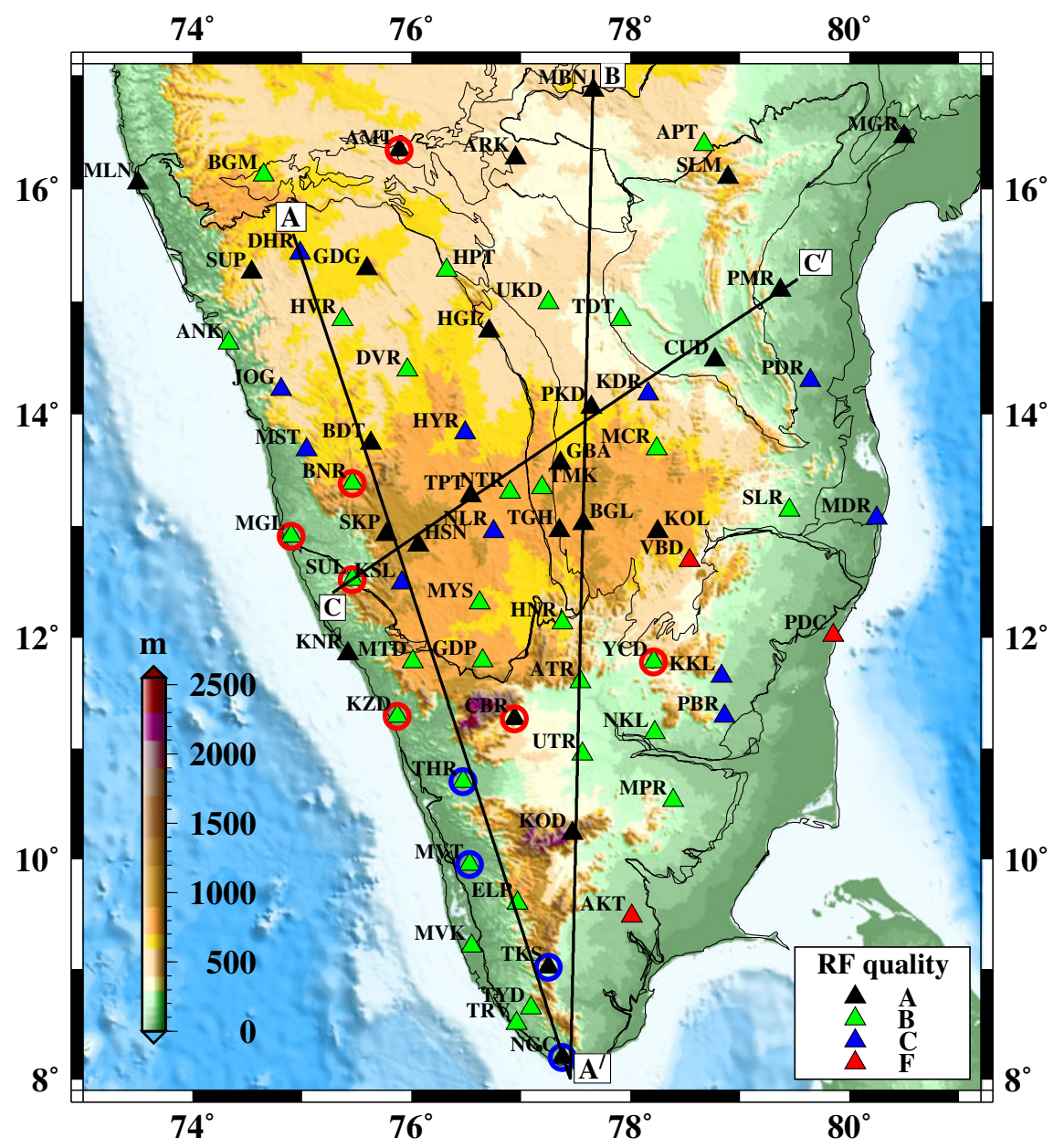

Figure 5. Quality of receiver functions computed at individual station in the study region along with topography. Thick lines show the locations of three profiles $\left(\mathrm{AA}^{\prime}, \mathrm{BA}^{\prime}\right.$ and $\left.\mathrm{CC}^{\prime}\right)$, along which $\mathrm{CCP}$ depth migrated receiver functions are plotted in figure 10. Stations circled are used in figure 13. 
examination of receiver functions from all the stations suggest three categories of seismograph locations representing the underlying geological complexity: (a) with clear $P$ to $S$ conversion $(P s)$ and multiples (PpPms, PpSms); (b) clear Ps and PpPms (or PpSms) and (c) only clear Ps. Example of these three classes of receiver functions from seismograph location is shown in figure 4 . Due to poor quality receiver functions for three stations, namely; PDC, VBD and AKT, we categorize them in $\mathrm{F}$ and are not included in our study. Using these criteria, distribution of quality seismograph location in South India is presented in figure 5.

\subsection{Crustal parameter estimation: $H-k$ stacking method}

To obtain Moho depth $(H)$ and average $V p / V s$ ratio $(k)$ (or Poisson's ratio $\sigma$ ) we used $H-k$ stacking technique of Zhu and Kanamori (2000) which exploits the fact that arrival times and amplitude of specific Moho converted phases and multiples appearing on radial receiver functions are determined by known functions of Moho depth $(H), k$ and average $V p$ in the crust. Since travel times used for crustal receiver function analysis are much less sensitive to $V p$ than to $V s$ (Zhu and Kanamori 2000 ), we assume an average $V p$ for the entire crust from previously obtained active source studies in that region. For a near true combination of $H$ and $k$ values, the quantity $S(H, k)$ is defined as the weighted sum of the receiver function amplitudes at the calculated times of predicted arrivals of $P s$, PpPms and PpSms+PsPms phases would expected to be maximum.

$$
S(H, k)=\sum_{j=1}^{N}\left[w_{1} r_{j}\left(t_{1}\right)+w_{2} r_{j}\left(t_{2}\right)-w_{3} r_{j}\left(t_{3}\right)\right],
$$

where $r_{j}(t)$ is the amplitude of receiver function for the $j$ th event, $t_{1}, t_{2}, t_{3}$ are predicted $P s, P p P m s$ and PpSms + PsPms arrival times corresponding to Moho depth $H$ and $k$, and $N$ being the total number of receiver functions. The $w_{i}$ 's are weighting factors, and $\sum w_{i}=1$ and

$$
\begin{gathered}
t_{1}=H\left[\sqrt{V s^{-2}-p^{2}}-\sqrt{V p^{-2}-p^{2}}\right] \\
t_{2}=H\left[\sqrt{V s^{-2}-p^{2}}+\sqrt{V p^{-2}-p^{2}}\right] \\
t_{3}=2 H \sqrt{V s^{-2}-p^{2}}
\end{gathered}
$$

where $w_{1}, w_{2}$ and $w_{3}$ are chosen to balance the contribution from the three phases in receiver function. Among the phases, Ps having higher amplitude over PpPms and PpSms is given higher weight than the other two. We also set $w_{1}>w_{2}+w_{3}$ because the later two phases have similar slope in $H-k$ plane. In this computation, we set $w_{1}=$ $0.6, w_{2}=0.3$ and $w_{3}=0.1$. We perform a grid


Figure 6. Stacked radial receiver functions for stations in South India, grouped according to their geological/structural proximity. 
search through $H$ and $k$ parameter space, and the parameter value corresponding to the maximum value of $S(H, k)$ can be considered as the best estimate.

Based on the modelling of several refraction profiles and receiver function analysis in South India (Kaila and Krishna 1992; Sarkar et al. 2001; Gupta et al. 2003a) average crustal $P$ wave velocity $(V p)$ is chosen to be $6.45 \mathrm{~km} / \mathrm{s}$. $H$ and $k$ are allowed to vary from $20-60 \mathrm{~km}$ (with $0.05 \mathrm{~km}$ increment) and 1.6-2.0 (with 0.002 increment), respectively. For stations where the multiples (in particular, $P p P m s)$ are not clear, $V p / V s$ ratio is taken from the neighbouring station. Poisson's ratio, which is a more useful tool to provide crustal composition than either $V p$ or $V s$ alone (Christensen 1996) can be calculated using,

$$
\sigma=0.5\left[1-\frac{1}{\left(V p^{2} / V s^{2}\right)-1}\right] .
$$

Parameters ( $H$ and $k$ ) uncertainty on $H-k$ stacking methods are estimated by using bootstrap method (Efron and Tibshirani 1986). From the entire set of receiver functions belonging to a station, receiver functions are chosen randomly with repetition. From the randomly selected receiver functions, 50 bootstrap samples are created. From each set of 50 bootstrap samples, $H$ and $k$ bootstrap values are calculated by using abovementioned technique. Uncertainties are calculated from 50 bootstrap values, using the following equation,

$$
\sigma_{\mathrm{boot}}=\left[\frac{1}{n-1} \sum_{i=1}^{n}\left(X_{i}-X_{\mathrm{avg}}\right)^{2}\right]^{1 / 2},
$$

where $X_{i}$ is the bootstrap value of a quantity ( $H$ or $k$ ) and $X_{\text {avg }}$ is the average bootstrap value of the quantity. In addition, for assessing uncertainty in $H$ and $k$ resulting from the choice of the average crustal $V p$, the $H-k$ stacks are recomputed using $V p$ of 6.35 and $6.55 \mathrm{~km} / \mathrm{s}$. For the variation of $V p$ for 6.35 and $6.55 \mathrm{~km} / \mathrm{s}$, maximum variation of $\sim 1.5 \mathrm{~km}$ and $\sim 0.01$ are observed in $H$ and $k$, respectively.

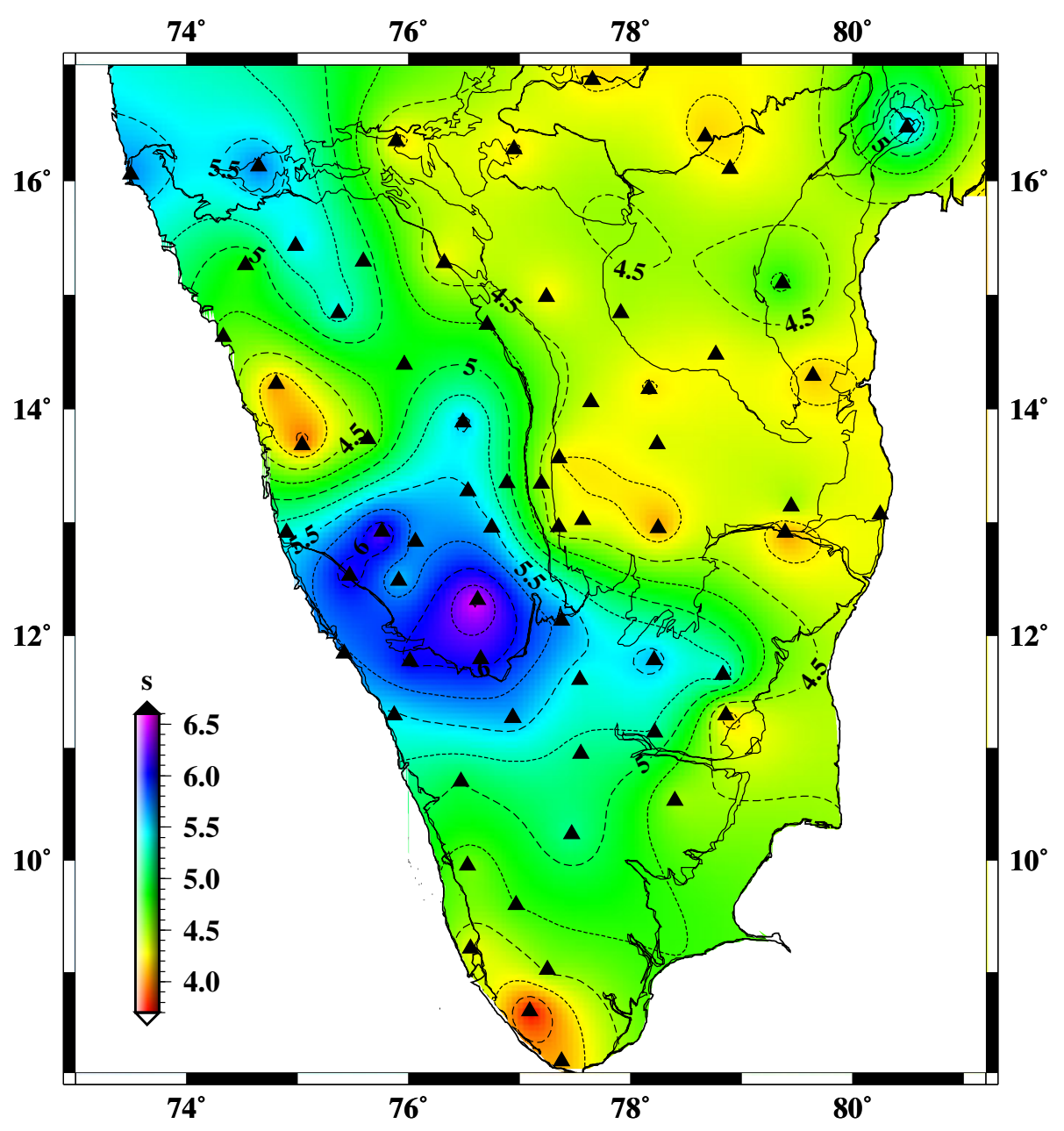

Figure 7. Moho converted $P s$ phase time for each station contours at every $0.25 \mathrm{~s}$ and annotated at every $0.5 \mathrm{~s}$. Seismograph stations (black triangles) and major tectonic features (solid lines) are also shown. 


\subsection{Common Conversion Point (CCP) stacking and depth migration}

The $H-k$ stacking method provides an average crustal thickness and $V p / V s$ ratio over an area with radius varying from $15-65 \mathrm{~km}$ assuming that the earth is flat layered and represented by a 1D velocity model. To study the lateral variability, depth migration of receiver functions is carried out using the Common Conversion Point (CCP) method (Dueker and Sheehan 1997). The amplitudes for each receiver function are back-projected
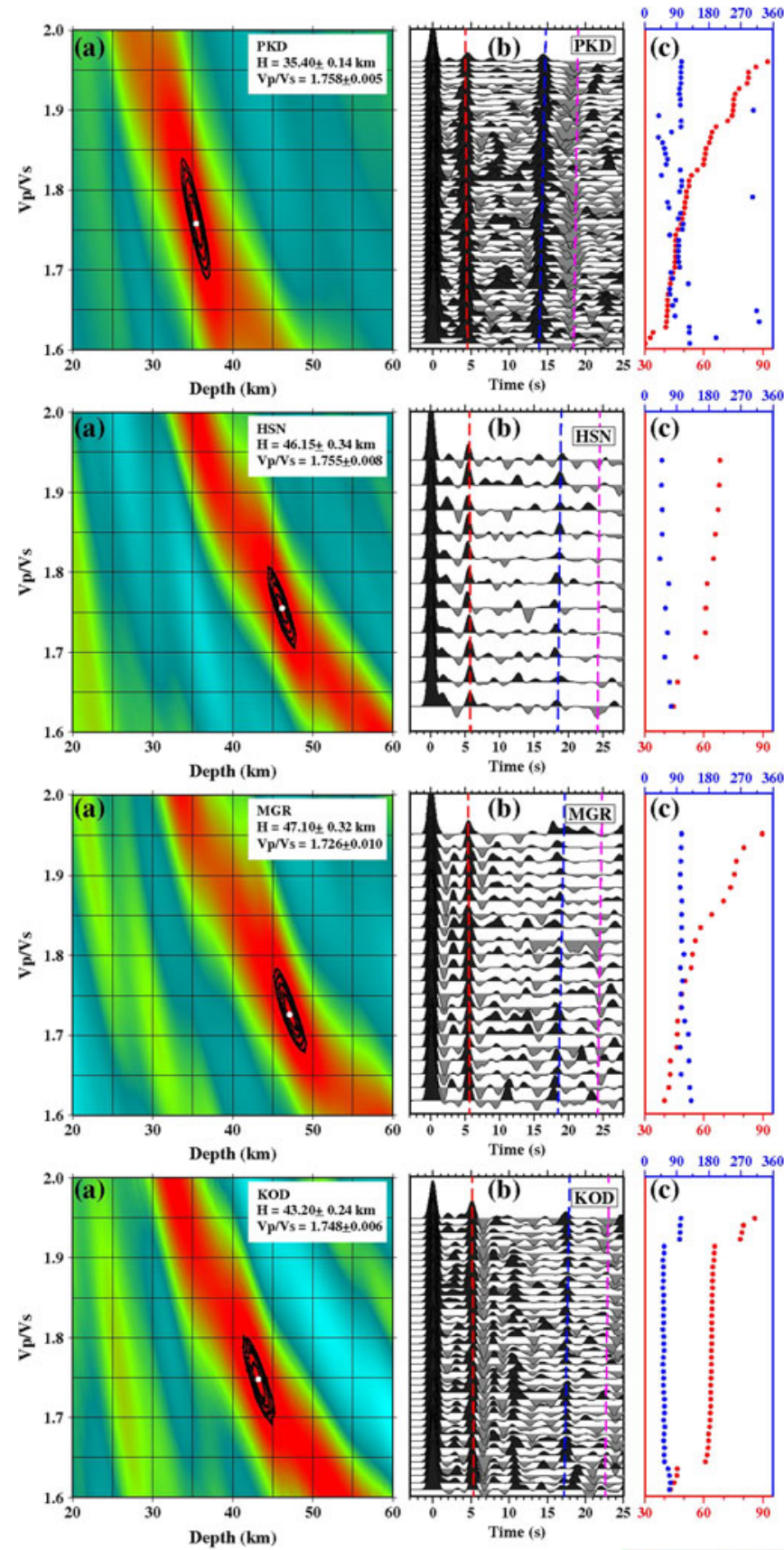


Figure 8. $H-k$ stacking results for selected stations with varying quality of receiver functions. (a) $H-k$ stacking results for the stations along their respective values and the corresponding errors are shown on the top right corner. White circle corresponds to the optimal values of $H$ and $k$. (b) Receiver functions used for $H-k$ stacking (as shown in a). Red, blue and magenta dashed lines correspond to the Ps, PpPms and PpSms timings, respectively, calculated using the optimum value of $H$ and $k$ values. (c) Epicentral distance (red circle) and backazimuth (blue circle) values for individual receiver function are plotted in panel (b). 
along a ray-path calculated for standard IASP91 model. This involves the following steps:

- Computation of the geographical locations of the piercing points of all $P$-to- $S$ conversions for each source-receiver pair at $1 \mathrm{~km}$ depth interval from 1 to $100 \mathrm{~km}$, using the IASP91 reference velocity model (Kennett and Engdahl 1991); and

- calculation of the travel times of $P$-to- $S$ converted phases from various depths using the relation:

$T_{P d s}=\int_{-d}^{0}\left[\sqrt{V s(z)^{-2}-p^{2}}-\sqrt{V p(z)^{-2}-p^{2}}\right] d z$

where $p$ denotes the ray parameter for the $P$ wave, $d$ the depth of the discontinuity and $V p(z)$ and $V s(z)$ are the $P$ and $S$ wave velocities at depth $z$ (Gurrola et al. 1994; Dueker and Sheehan 1997), respectively. The volume along a profile is divided into block of $1 \mathrm{~km}$ height and length but with a wider dimension perpendicular to the profile. Amplitudes of the rays traversing each bin are summed and averaged to have amplitude at that bin using the relation:

$$
A(d)=\frac{1}{N} \sum_{i=1}^{N} A_{i}\left(T_{P d s}^{i}\right),
$$

where $A(d)$ is the stacking amplitude for a candidate discontinuity at depth $d, N$ is the number of receiver functions piercing particular depth $d$, $A_{i}\left(T_{P d s}^{i}\right)$ is the amplitude of the $i$ th receiver function at time $T_{P d s}^{i}$, and $T_{P d s}^{i}$ is the travel times of $P$-to- $S$ converted phases of the $i$ th receiver function at depth $d$. It has been shown that a $4 \%$ change in the $V p / V s$ ratio can perturb the crustal thickness by $3 \mathrm{~km}$, whereas the same percentage change in $V p$ would cause an error of the order of only $1 \mathrm{~km}$ (Zhu and Kanamori 2000).

\section{Results}

\subsection{Nature of the crust}

To study the nature of Moho conversion in $P s$ phase and other intra-crustal conversion phase, we stacked receiver function for individual stations in narrow epicenter and backazimuth ranges. Figure 6 shows stacked receiver function of individual stations arranged by different geological blocks of South India Shield, which show remarkable spatial coherence of Moho converted Ps phase with the surface geology and compositional boundaries. Important observations from the receiver function data include: the stations in the late Archean EDC and the Proterozoic $\mathrm{CB}$ are characterized by $P s$ time $\sim 4.5 \mathrm{~s}$, CG have $P s$ time of $4.5-5 \mathrm{~s}$ and almost no intra-crustal conversion. $P s$ time in the WDC is $\sim 5-6 \mathrm{~s}, \mathrm{EG} \sim 4.5-5.6 \mathrm{~s}$, WG $\sim 4.7-5.7 \mathrm{~s}$ and SGT $\sim 3.7-6$ s with significant presence of intracrustal conversion. $P s$ timings in the northern part of WDC is $\sim 4.3 \mathrm{~s}$ compared to $>5 \mathrm{~s}$ in south. The

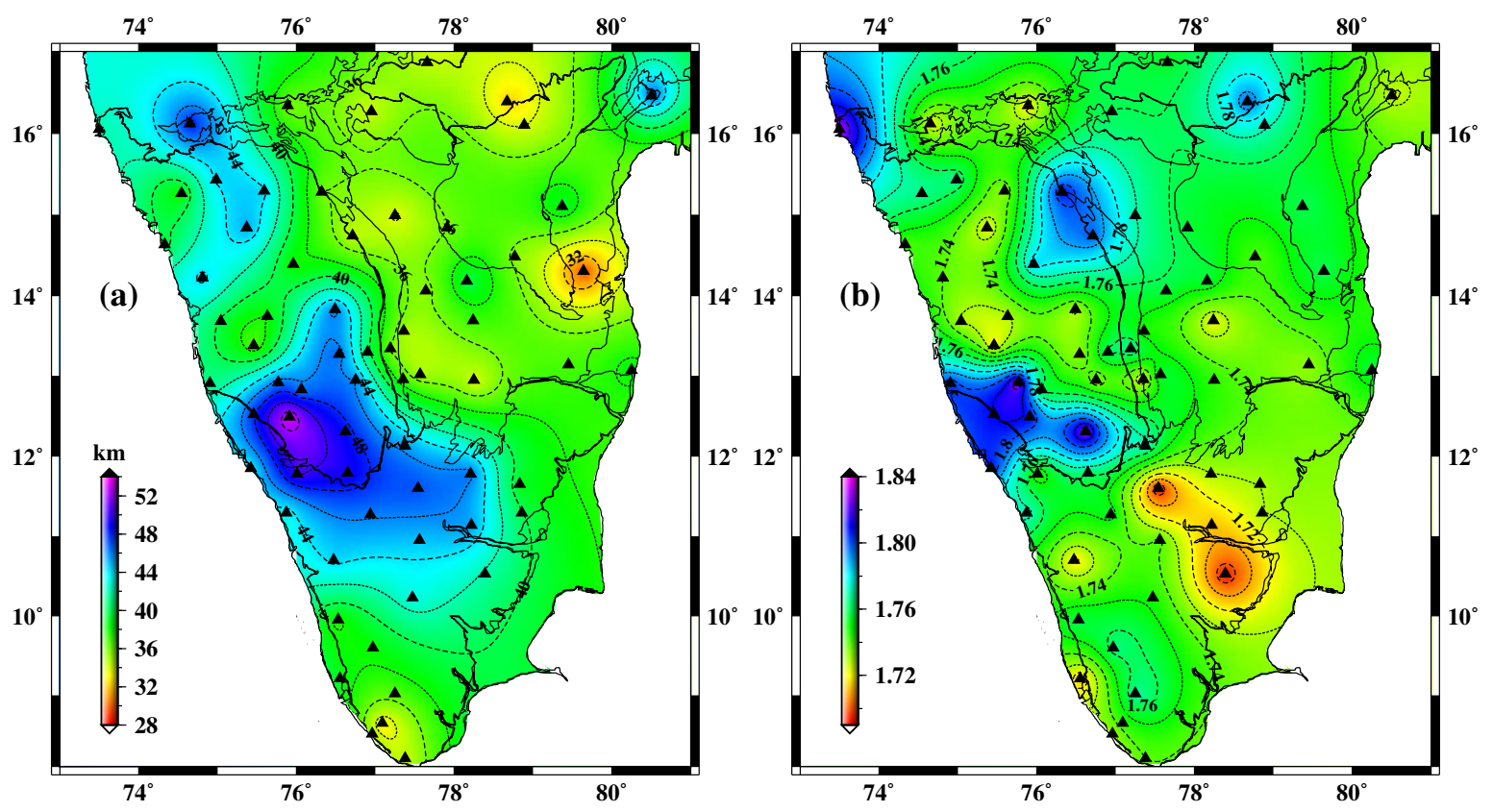

Figure 9. (a) Moho depth, and (b) $V p / V s$ ratio variation maps of South India using $H-k$ stacking method. Stations (black triangles) and tectonics (solid lines) are also projected on the plots. 
stations in Archean SGT (north of NKSZ) have $P s$ time $>5 \mathrm{~s}$ while the stations in Neo-Proterozoic $\mathrm{MB} / \mathrm{KKB}$ have $P s$ time $\sim 4.5 \mathrm{~s}$. The time of Mohoconverted $P s$ phase from individual station is contoured in figure 7. Largest Moho-converted Ps time $(>6 \mathrm{~s})$ is observed beneath mid-Archean greenstone belt in the southern part of WDC. Considering $V p$ $\sim 6.4 \mathrm{~km} / \mathrm{s}$ and $V s \sim 3.7 \mathrm{~km} / \mathrm{s}$, and ray parameter $p \sim 0.0576 \mathrm{~s} / \mathrm{km}$, corresponding to epicentral distance of $67^{\circ}$, we find that $1 \mathrm{~s}$ of $t_{1}$ ( $P s$ arrival) corresponds to $\sim 8 \mathrm{~km}$ Moho depth $(H)$ variation (using equation 3 ). We, therefore infer significant Moho depth variations (upto $10 \mathrm{~km}$ ) among the different geological provinces of South India.
$H-k$ results for few stations from different geological provinces along with observed receiver function and theoretical Ps (red dashed line), PpPms (blue dashed line) and PpSms (magenta dashed line) timings calculated from optimum value of $H$ and $k$ are presented in figure 8 . To examine the regional variation of Moho depth $(H)$ and $k$ in the South India Shield, we collected these parameters for each station, and interpolated over a $10 \times 10 \mathrm{~km}$ grid using Generic Mapping Tools (Wessel and Smith 1998). Moho depth and $V p / V s$ ratio variations are shown in figure 9. Details of individual station are presented in table 1. The EDC with surface topography of 400-600 m, has Moho



Figure 10. Common Conversion Point (CCP) depth migrated receiver function along three profiles (shown in figure 5). $V p / V s$ ratio (red star) and Moho depth (white star) obtained from $H-k$ stacking methods are projected on each plot. Red dashed lines are the boundary between two geological provinces. 
depth of $\sim 32-38 \mathrm{~km}$. Despite having similar topography as EDC, WDC shows large variation in the Moho depth: 38-46 km in north and 46-54 km in its south. Using normal density contrast across Moho, this should lead to an elevation of more than $3 \mathrm{~km}$ in the southern part of WDC. However, in view of the nearly flat topography $(\sim 600 \mathrm{~m})$, we speculate that the region is compensated by high density (and high velocity) material in the lowermost crust. In the northern part of SGT (north of NKSZ), Moho depth varies from 39-50 km, while in $\mathrm{MB} / \mathrm{KKB}$, it varies mostly from $33-39 \mathrm{~km}$. In EG and WG, Moho depth varies from 39-47 km, 40-43 km, respectively. Interestingly we observe similar $V p / V s$ ratio $(\sim 1.72-1.76)$ in EDC, EG and $\mathrm{CG}$, and higher $V p / V s$ ratio $(\sim 1.73-1.83)$ in $\mathrm{WG}$ and WDC. In northern part of SGT, $V p / V s$ ratio mostly varies from 1.69-1.75, while in $\mathrm{MB} / \mathrm{KKB}$, it varies from $1.71-1.76$.

CCP depth migrated section with $V p / V s$ ratio along three profiles (shown in figure 5 : $\mathrm{N}-\mathrm{S}$ profile $\mathrm{AA}^{\prime}$ and $\mathrm{BA}^{\prime}, \mathrm{W}-\mathrm{E}$ profile $\mathrm{CC}^{\prime}$ ) are presented in figure 10. To compare the Moho depth computed from two different approaches, Moho depth calculated from $H-k$ methods are projected on the CCP plot. Figure 10 shows a clear agreement between both the methods. Due to limited backazimuthal coverage with most of the arrivals from the NE and SE directions and station density along the profile, it has not been possible to provide continuous coverage of the Moho. Ideally, to have well defined continuous image of Moho, the stations separation should be $15-20 \mathrm{~km}$. Nevertheless, the Moho with most prominent signal is clearly visible in all the profiles. Two N-S profiles $\mathrm{AA}^{\prime}$ and $\mathrm{BA}^{\prime}$ passing through the WDC and EDC to SGT show clear Moho deepening in southern part of the WDC reaching over $50 \mathrm{~km}$; northern SGT with Moho depth of $\sim 45 \mathrm{~km}$ compared to $\sim 38 \mathrm{~km}$ Moho beneath $\mathrm{MB} / \mathrm{KKB}$. We also observe negative phase (red colour) in few stations in the MB/KKB. This is further discussed in the next section. The profile $\mathrm{CC}^{\prime}$ through the oldest part of the craton (greenstone belt in the southern part of WDC) to EDC shows the thickest crust of $\sim 50 \mathrm{~km}$ in the WDC, while in the EDC it is around $\sim 37 \mathrm{~km}$. Figure 10 clearly shows that CSB is the boundary between WDC and EDC.

To examine whether the topography is compensated by the change in crustal thickness, we plotted elevation against Moho depth for all the stations in figure 11(a). We do not observe any correlation between the two parameters. The lack of correlation between Moho depth and elevation indicates that variations in crustal thickness do not have a first-order influence on topography in South India and lateral variation of density is an important factor in controlling the isostatic upliftment.
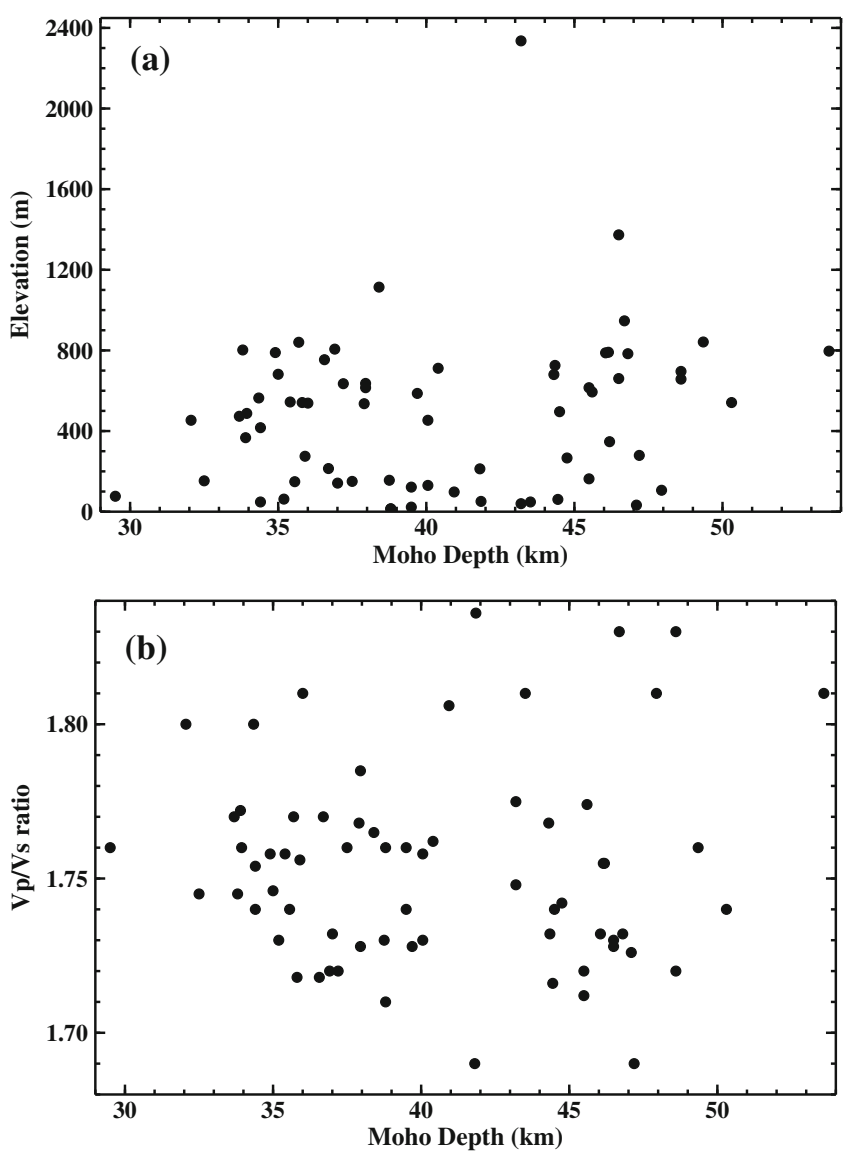

Figure 11. Plots of Moho depth versus elevation (a), and $V p / V s$ ratio (b) for all the stations of South India shield listed in table 1 .

Further, absence of any clear correlation between Moho depth and $V p / V s$ ratio (figure 11b) indicates the complex crustal structure in the entire region, and this can be investigated by detailed modelling of receiver function. This is beyond the scope of present investigation and is being pursued separately.

\subsection{Evidence for mid-lithosperic discontinuity}

Several recent studies have proposed a midlithospheric discontinuity of debatable origin existing under several cratons (Thybo and Perchuc 1997; Abt et al. 2010). This has also been revealed in several recent receiver-function studies that show negative impedance contrast at depths between 60 and $150 \mathrm{~km}$ (Fischer et al. 2010). This interface is too shallow to be regarded as the Lithosphere-Asthenosphere Boundary, but the petrological origin of this additional discontinuity and its assumed distinctness from the LAB remain uncertain. A mid-lithospheric interface has been observed by Savage and Silver (2008) at $150 \mathrm{~km}$ depth beneath the northeastern part of the Kalahari craton using $S$ receiver functions that 
was interpreted to mark a change in composition. They interpreted the boundary due to refertilized depleted lithosphere by basaltic melt rich in iron and volatiles possibly related to the eruption of the Karoo flood-basalt and associated magma intrusions. A mid-lithospheric velocity reduction is also detected underneath central and western Australia at a depth range between 69 and $85 \mathrm{~km}$ combining results from $P$ and $S$ receiver functions (Ford et al. 2010). It is assumed to represent either a change in grain size or fabric, vertical variations in mantle composition or low-velocity melt accumulation. Abt et al. (2010) utilized $P$ and $S$ receiver functions as well velocity profiles derived from surface wave data from United States. They reported a similar discontinuity at depth between 59 and $113 \mathrm{~km}$ beneath the cratonic core and certain phanerozoic regions of the United States. The authors proposed alteration of the cratonic lithosphere by melt or the lower boundary of an ancient, highly depleted layer of the lithosphere to explain the observed interface. $S$ receiver functions have further revealed the existence of a mid-lithospheric discontinuity beneath the Canadian Shield (Miller and Eaton 2010). Recent studies by Wolbern et al. (2012) have also shown the evidence of the discontinuity under the Tanzanian craton at depth of $50-100 \mathrm{~km}$ from $S$ receiver functions. Kumar et al. (2007) reported low velocity at a depth of $80-100 \mathrm{~km}$ at a few locations in India based on the (a)

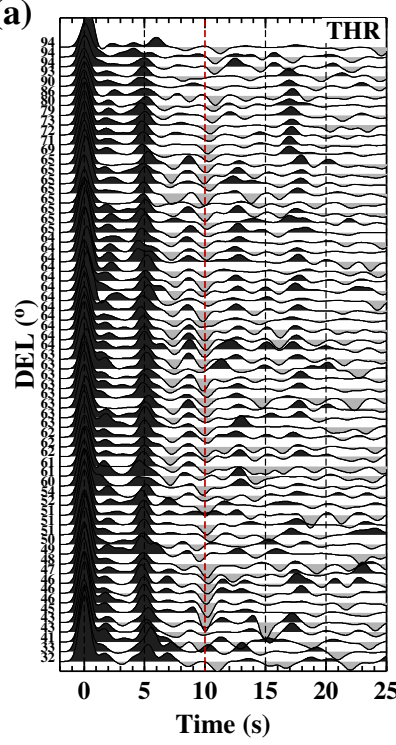

(b)

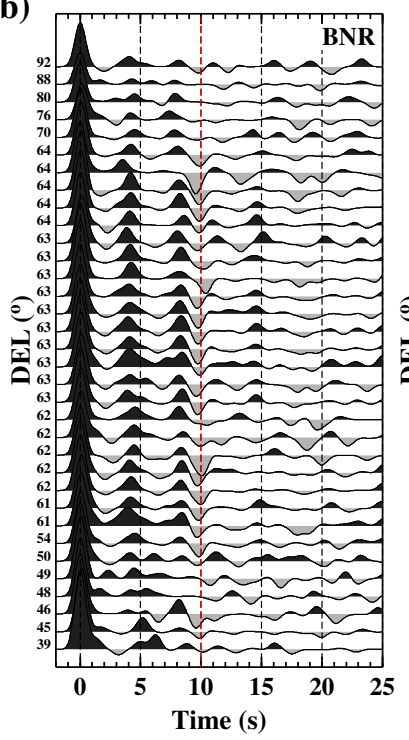

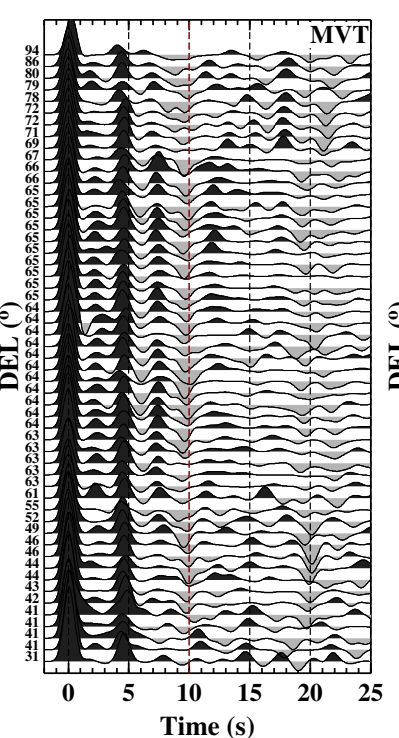
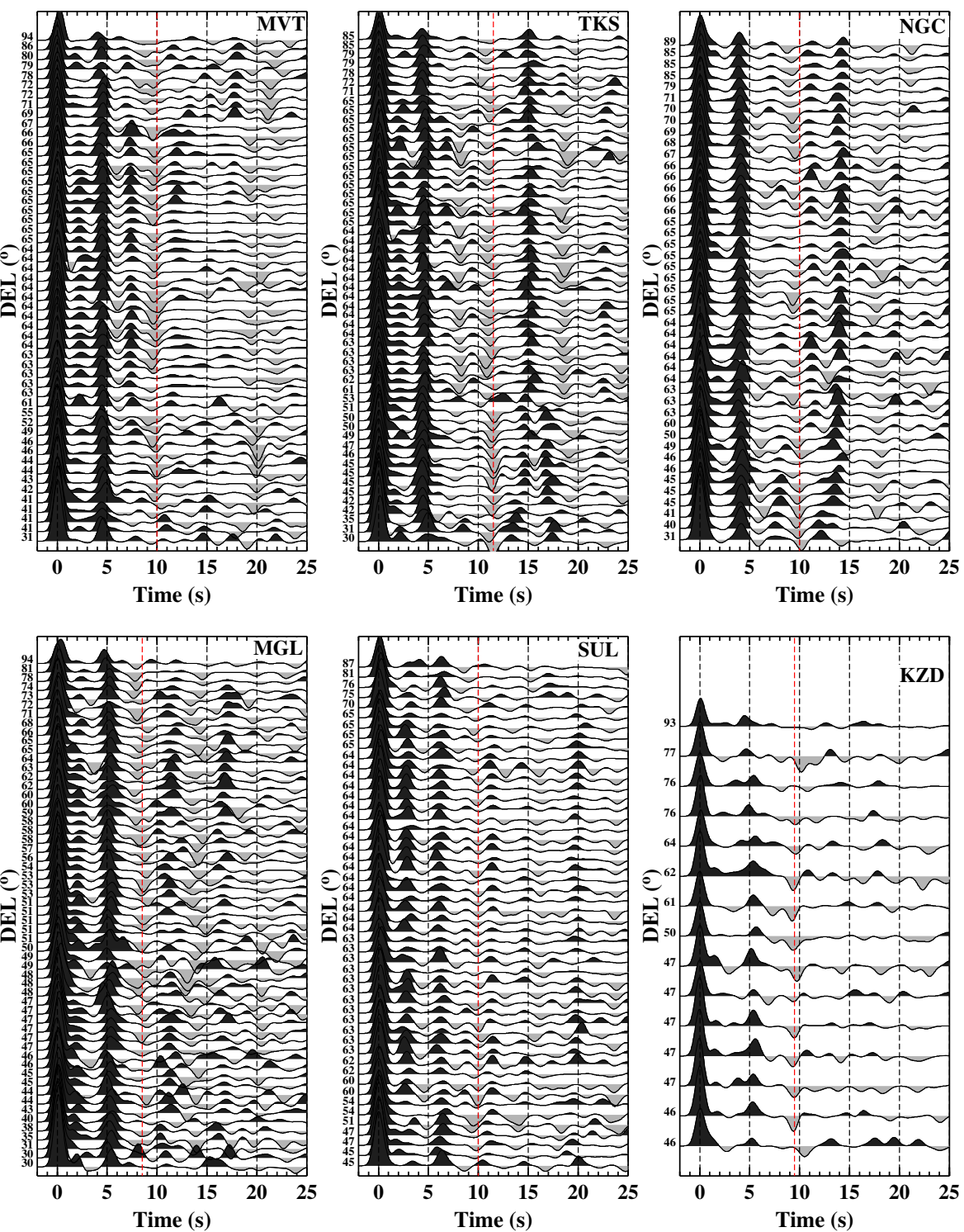



Figure 12. Receiver function plot for (a) sharp negative phase and (b) weak negative phase observed at $\sim 10-12 \mathrm{~s}$. RFs are plotted with increasing epicentral distance (DEL, in degree) from eight seismograph stations. Negative phase is marked by red dashed line. 


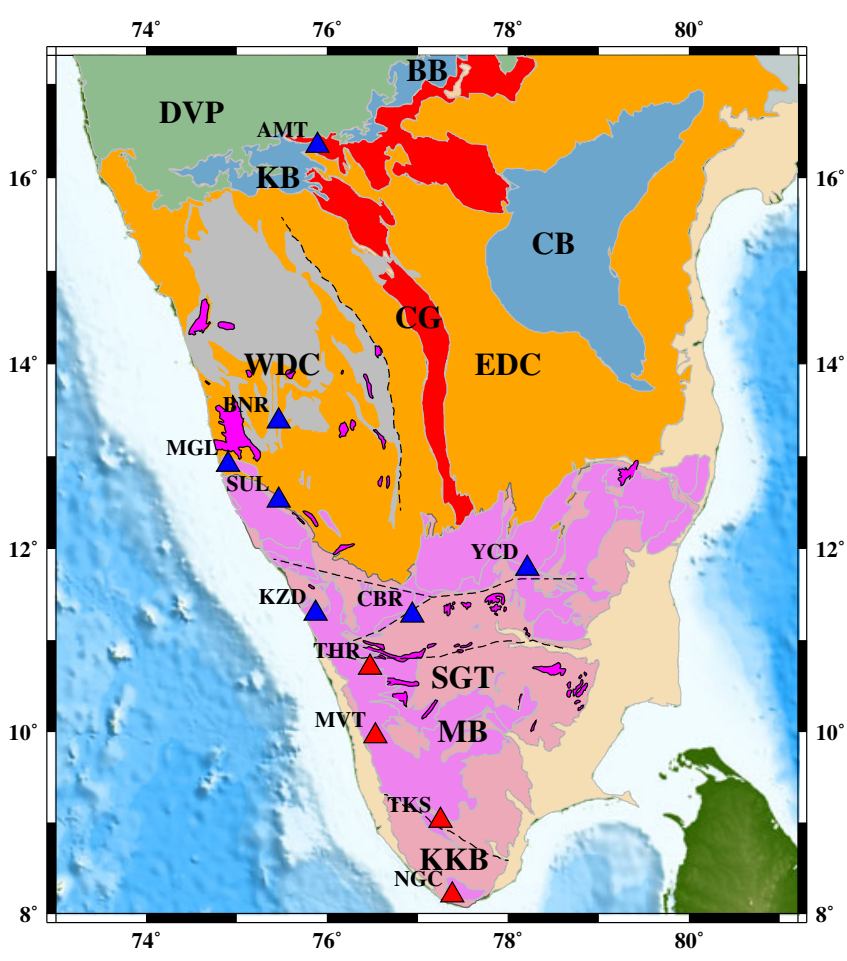

Figure 13. Location of seismograph stations where negative phase (LVZ) is observed. Stations with sharp and weak negative phase observed are marked by red and blue triangles, respectively.

analysis of $S$ receiver functions and interpreted it as due to shallow LAB.

While analysing receiver functions, we observed a negative phase between 10 and $12 \mathrm{~s}$ at several locations in South India both in the mid Archean segments and Neo-Proterozoic terrain of South India. We present the receiver functions at selected stations and mark the negative phase (figure 12a, b), which corresponds to a source depth of $80-100 \mathrm{~km}$. The negative polarity could be a converted phase from velocity inversion or may be a multiple arising from a shallower interface. These could be discriminated based on the arrival time-distance relation. For a converted phase from a depth, the arrival time decreases with the epicenter distance while for a seismic phase reverberating from this depth the time of arrival would increase with the distance. We examined all the dataset using this criterion and concluded that the observed phase at $\sim 10-12 \mathrm{~s}$ is conversion from the top of low velocity layer. Conversion of this negative $P$ to $S$ phase at $10-12 \mathrm{~s}$, in terms of depth suggests the presence of low velocity at $\sim 85-100 \mathrm{~km}$. Figure 13 shows location of seismic stations where such LVZ is observed. The LVZ is sharp and consistent in the Neo-Proterozoic domain affected by the Pan-African event (Rai et al. 2008).

\section{Discussions and conclusions}

Global review of seismic structure suggests that the Proterozoic crust has a thickness of 40$50 \mathrm{~km}$, while Archean crust is only $27-40 \mathrm{~km}$ thick (Durrheim and Mooney 1994). Alternatively, Rudnick and Fountain (1995) and Tugume et al. (2012) suggested that both Archean and Proterozoic crusts have similar crustal thickness (37$45 \mathrm{~km}$ ). Zandt and Ammon (1995) using data distributed across the globe, found crustal thickness of shields and platforms to be between $\sim 37$ and $42 \mathrm{~km}$ and $V p / V s$ ratio to be 1.78 . Chevrot and van der Hilst (2000), using broad-band receiver function measurements from Australia, found no significant variation in $V p / V s$ ratio between the Archean and Proterozoic crust. However, thickness of the crust shows remarkable variability from thinner Archean crust $(\sim 35 \mathrm{~km})$ to a thicker Proterozoic crust $(\sim 45 \mathrm{~km})$. Detailed analysis of observations from South African Seismic Experiment (Nguuri et al. 2001; Nair et al. 2006) shows undisturbed Archean crust (Zimbabwe and Kaapvaal cratons) having thinner crust $(38 \mathrm{~km})$ and lower $V p / V s$ ratio (1.73), compared with a thicker crust $(\sim 43 \mathrm{~km})$ and higher $V p / V s$ ratio $(\sim 1.78)$ for a disturbed Archean terrain (Bushveld mafic complex). Seismological measurements from the Canadian Shield (Thompson et al. 2010) suggest transparent and felsic crust $(V p / V s \sim 1.73)$ with sharp Moho at 35-40 km depth beneath the mid-Archean (3.2-3.6 Ga) and late $(2.5-2.8 \mathrm{Ga})$ Archean crustal domains.

We find Moho depths, $32-38 \mathrm{~km}$ in the late Archean EDC and CG, 34-36 km in the proterozoic CB, 38-46 km in the 2.7-3 Ga Dharwar Basin, $\sim 39-50 \mathrm{~km}$ in the Archean SGT and $33-39 \mathrm{~km}$ in the Pan-African belt. The thickest crust $(\sim 54 \mathrm{~km})$ is observed in the mid-Archean greenstone belt in the southern part of WDC. The crustal thickness estimate for the late-Archean EDC is similar to the global average $(30-40 \mathrm{~km})$. The midArchean nucleus in WDC is, however, considerably $(>10 \mathrm{~km})$ thicker than that of an average Archean Shield and is at variance with the hypothesis that older crust was thinner.

Compressional wave velocity has been widely used to infer the composition of the crust. However, availability of three-component seismic measurements of earthquake waveform allow us to place tighter constraint on the crustal composition using $V p / V s$ ratio instead of velocity of either $P$ or $S$ wave alone. Average crust $V p / V s$ ratio is dependent on the cracks, porosity, temperature, and mineralogy of the rock. At higher pressure, $\sim 200 \mathrm{MPa}$, laboratory measurements suggest that it essentially depends on the silica content in the rock - higher $V p / V s$ ratio for a more mafic crust 
(Christensen 1996). For the common igneous and metamorphic rocks, it is controlled by the relative presence of quartz $(V p / V s \sim 1.49)$ and plagioclase $(V p / V s \sim 1.87)$. For common rock type, $V p / V s$ ratio varies from 1.63 to 2.08 . For lower crustal rocks, low $V p / V s$ ratio $(<1.76)$, intermediate $V p / V s$ ratio $(1.76-1.81)$ and high $V p / V s$ ratio $(>1.81)$ are characteristic of felsic, intermediate and mafic composition, respectively. For example, granite rock has a characteristic $V p / V s$ ratio of 1.71 , while for intermediate composition rocks (e.g., diorite) it is 1.78 , and for mafic rocks (e.g., gabbro) 1.87 (Christensen 1996). We observe $V p / V s$ ratio $\sim 1.7-1.76$ in most parts of the South India, which suggests felsic to intermediate crust. The exception being the part of the WG and the southern part of the WDC (greenstone belt) with $V p / V s>1.81$, suggestive of mafic crust beneath them.

In summary, the exposed mid-Archean crust of western Dharwar is characterized by thick $(\sim 50 \mathrm{~km})$ and average mafic composition in contrast with a thinner and felsic crust in late-Archean and Proterozoic terrains. Considering a $\sim 15 \mathrm{~km}$ depth of burial of rocks currently expose on surface in the WDC, we speculate a Himalaya-Tibet like crustal thickness of $\sim 70 \mathrm{~km}$ beneath the midArchean crust. Presently, the Dharwar Craton has almost flat topography. This is possible due to presence of mafic crustal root beneath the south WDC as also reflected in high average $V p / V s$ for the crust. The flat Moho and felsic crust elsewhere in South India could be a consequence of delamination of mafic lower crust.

In the shallower mantle, at depth of $85-100 \mathrm{~km}$, we observe a negative polarity phase at several locations in the south India, prominantly in the Pan-African granulite terrain. This could be a fossil mid-lithospheric low velocity. Pacific Ocean like subduction has been argued in the Pan-African terrain of South India (Santosh et al. 2009). In this framework, we examine the relevance of pervasive low velocity at depth of $70-100 \mathrm{~km}$ observed in the Pacific belt and its possible implication to the observed low velocity in South India. It is argued that the low velocity observed in the Pacific subduction zone is related to mineralogy of the subducted crust (Gubbins et al. 1994), but the specific mineralogy of the low velocity layer remain controversial and is a subject of intense research (Connolly and Kerrick 2002). The other causative sources for low velocity, discussed above remain equally debatable in the absence of any credible theoretical, experimental support. This calls for a more sustained research in petrology and mineral physics to understand the cause for such a shallow mantle low velocity in the continental interior. Equally important is to sharpen seismological tools to image and quantify the properties of the low velocity zones.

\section{Acknowledgements}

Seismological field experiment was supported by the INDEX Research project of the CSIR-NGRI. This study is a part of the $\mathrm{PhD}$ dissertation of $\mathrm{KB}$. He was supported by a research fellowship from CSIR. SSR was supported by JC Bose National Fellowship of the Dept. of Science and Technology, New Delhi. The authors greatly appreciate help of P Mahesh, V Pavan Kumar, Utpal Saikia, Somasish Bose, K Nagaraju and Gyan Singh Meena during the field deployment of seismographs.

\section{References}

Abt D L, Fischer K M, French S W, Ford H A, Yuan H and Romanowicz B 2010 North America lithospheric discontinuity structure imaged by Ps and Sp receiver functions; $J$. Geophys. Res. 115 B09301, doi: 10.1029/2009JB006914.

Anderson D L 2006 Speculations on the nature and cause of mantle heterogeneity; Tectonophys. 416 7-22.

Besse J and Courtillot V 1988 Paleogeographic maps of the continents bordering the Indian Ocean since the Early Jurassic; J. Geophys. Res. 93 11,791-11,808.

Bouhallier H, Chardon D and Choukroune P 1995 Strain patterns in Archaean dome-and-basin structures: The Dharwar craton (south India); Earth Planet. Sci. Lett. 135 57-75.

Calvert A J, Sawyer E W, Davis W J and Ludden J N 1995 Archean subduction inferred from seismic images of a mantle suture in the Superior Province; Nature $\mathbf{3 7 5}$ 670-674.

Chadwick B, Vasudev V N and Hedge G V 2000 The Dharwar craton, south India interpreted as the result of late Archaean oblique convergence; Precamb. Res. 99 91-111.

Chevrot S and van der Hilst R D 2000 The Poisson ratio of the Australian crust: Geological and geophysical implications; Earth Planet. Sci. Lett. 183 121-132.

Christensen N I 1996 Poisson's ratio and crustal seismology; J. Geophys. Res. 101 3139-3156.

Condie K C 2005 Earth as an evolving planetary system (Amsterdam: Elsevier Academic Press), 447p.

Connolly J A D and Kerrick D M 2002 Metamorphic controls on seismic velocity of subducted oceanic crust at 100 $250 \mathrm{~km}$ depth; Earth Planet. Sci. Lett. 204 61-74.

Crotwell H P, Owens T J and Ritsema J 1999 The TauP Toolkit: Flexible seismic travel-time and ray-path utilities; Seismol. Res. Lett. 70 154-170.

Davies G F 1992 On the emergence of plate tectonics; Geology 20 963-966.

de Wit M J, de Ronde C E J, Tredoux M, Roering C, Hart R J, Armstrong R A, Green R W E, Peberdy E and Hart $\mathrm{R}$ A 1992 Formation of an Archean continent; Nature 357(6379) 553-562.

de Wit M J 1998 On Archean granites, greenstones, cratons, and tectonics: Does the evidence demand a verdict?; Precamb. Res. 91 181-226. 
Dhuime B, Hawkesworth C J, Cawood P A and Storey C D 2012 A change in the geodynamics of continental growth 3 billion years ago; Science 335 1334-1336, doi: $10.1126 /$ science.1216066.

Drury S A, Harris N B, Holt R W, Reeves-Smith G J and Wightman R T 1984 Precambrian tectonics and crustal evolution in south India; J. Geol. 92 3-20.

Dueker K G and Sheehan A F 1997 Mantle discontinuity structure from midpoint stacks of converted $\mathrm{P}$ to $\mathrm{S}$ waves across the Yellowstone hotspot track; J. Geophys. Res. 102 8313-8327.

Durrheim R J and Mooney W D 1994 Evolution of the Precambrian lithosphere: Seismological and geochemical constraints; J. Geophys. Res. 99 15,359-15,374.

Efron B and Tibshirani R 1986 Bootstrap methods for standard errors, confidence intervals, and other measures of statistical accuracy; Stat. Sci. 1 54-77.

Fischer K M, Ford H A, Abt D L and Rychert C A 2010 The lithosphere-asthenosphere boundary; Ann. Rev. Earth Planet. Sci. 38 551-575, doi: 10.1146/annurevearth040809-152438.

Ford $\mathrm{H}$ A, Fischer $\mathrm{K}$ M, Abt D L, Rychert C A and Elkins-Tanton L T 2010 The lithosphere asthenosphere boundary and cratonic lithospheric layering beneath Australia from Sp wave imaging; Earth Planet. Sci. Lett. 300 299-310, doi: 10.1016/j.epsl.2010.10.007.

Gao S, Zhang B R, Jin Z M, Kern H, Luo T C and Zhao Z D 1998 How mafic is the lower continental crust?; Earth Planet. Sci. Lett. 161 101-117.

Gaur V K and Priestley K F 1996 Shear wave velocity structure beneath the Archaean granites around Hyderabad inferred from receiver function analysis; Proc. Indian Acad. Sci. (Earth Planet. Sci.) 105 1-8.

Gubbins D, Barnicoat A and Cann J 1994 Seismological constraints on the gabbro-eclogite transition in subducted oceanic crust; Earth Planet. Sci. Lett. 122 89-101.

Gupta S, Rai S S, Prakasam K S, Srinagesh D, Bansal B K, Chadha R K, Pristley K and Gaur V K 2003a The nature of the crust in southern India: Implication for Precambrian crustal evaluation; Geophys. Res. Lett. 30 1419, doi: 10.1029/2002GL016770.

Gupta S, Rai S S, Prakasam K S, Srinagesh D, Chadha R K, Prisetley K and Gaur V K 2003b First evidence for anomalous thick crust beneath mid-Archean western Dharwar craton; Curr. Sci. 84 1219-1226.

Gurrola R W, Minster J B and Owens T 1994 The use of velocity spectrum for stacking receiver functions and imaging upper mantle discontinuities; Geophys. J. Int. $117427-440$.

Hawkesworth C J and Kemp A I S 2006 Evolution of the continental crust; Nature 443 811-817.

Jagadeesh S and Rai S S 2008 Thickness, composition and evolution of the Indian Precambrian crust; Precamb. Res. $1624-15$

Jarchow C M and Thompson G A 1989 The nature of the Mohorovicic discontinuity; Ann. Rev. Earth Planet. Sci. $17475-506$.

Julia J, Jagadeesh S, Rai S S and Owens T J 2009 Deep crustal structure of the Indian Shield from joint inversion of $\mathrm{P}$-wave receiver functions and Rayleigh-wave group velocities: Implications for Precambrian evolution; $J$. Geophys. Res. 114 B10313, doi: 10.1029/2008JB006261.

Kaila K L and Krishna V G 1992 Deep seismic sounding studies in India and major discoveries, In: Seismology in India - An overview (eds) Gupta H K and Ramaseshan S, Curr. Sci. (Spec. Issue) 62 117-154.

Kennett B and Engdahl E 1991 Travel times for global earthquake location and phase identification; Geophys. J. Int. $105429-465$.
Kiselev S, Vinnik L, Oreshin S, Gupta S, Rai S S, Singh A, Kumar M R and Mohan G 2008 Lithosphere of the Dharwar craton by joint inversion of $\mathrm{P}$ and $\mathrm{S}$ receiver functions; Geophys. J. Int. 173(3) 1106-1118.

Kumar N, Singh A P and Singh B 2011 Insights into the crustal structure and geodynamic evolution of the southern granulite terrain, India, from isostatic considerations; Pure Appl. Geophys. 168 1781-1798.

Kumar P, Yuan X H, Kumar M R, Kind R, Li X Q and Chadha R K 2007 The rapid drift of the Indian tectonic plate; Nature 449 894-897.

Ligorria J P and Ammon C J 1999 Iterative deconvolution and receiver-function estimation; Bull. Seismol. Soc. Am. $358233-265$.

Meen J K, Roger J J W and Fullargar P D 1992 Lead isotopic compositions of the Western Dharwar Craton, south India: Evidence for distinct middle Archaean terranes in a late Archaean craton; Geochim. Cosmochim. Acta 56 $2455-2470$

Meissner R 1986 The Continental Crust: A Geophysical Approach; International Geophysics Series, vol. 34, Academic Press.

Miller M S and Eaton D W 2010 Formation of cratonic mantle keels by arc accretion: Evidence from S receiver function; Geophys. Res. Lett. 37 L18305, doi: 10.1029/2010GL044366.

Mitra S, Pristley K, Gaur V K and Rai S S 2006 Shear wave velocity structure of the south Indian lithosphere from Rayleigh wave phase velocity measurements; Bull. Seismol. Soc. Am. 96 1551-1559.

Nagel T J, Hoffman J E and Munker C 2012 Generation of EoArchean tonalite-trondhjemite-grandiorite series from thickened mafic arc crust; Geology 40 375-378, doi: 10.1130/G32729.1.

Nair S K, Gao S S, Liu K H and Silver P G 2006 South African crustal evolution and composition: Constraints from receiver function studies; J. Geophys. Res. 111 B02304, doi: 10.1029/2005JB003802.

Naqvi S M and Rogers J J W 1996 Precambrian Geology of India, Clarendon Press, New York.

Nguuri T K, Gore J, James D E, Webb S J, Wright C, Zengeni T G, Gwavava O and Snoke A 2001 Crustal structure beneath southern Africa and its implications for the formation and evolution of Kaapval and Zimbabwe craton; Geophys. Res. Lett. 28 2501-2504.

Nelson K D 1991 A unified view of craton evolution motivated by recent deep seismic reflection and refraction results; Geophys. J. Int. 105 25-35.

Peucat J J, Bouhallier H, Fanning C M and Jayananda M 1995 Age of the Holenarsipur greenstone belt, relationship with surrounding gneisses (Karnataka, south India); J. Geol. 103 701-710.

Rai A, Gaur V K, Rai S S and Priestley K 2008 Seismic signatures of the Pan-African orogeny: Implication for southern Indian high-grade terranes; Geophys. J. Int. 176 $518-528$

Rai S S, Priestley K, Prakasam K S, Srinagesh D, Gaur V K and Du Z 2003 Crustal shear velocity structure of the south Indian shield; J. Geophys. Res. 108(B2) 2088, doi: 1029/2002JB001776.

Raith M, Raase P, Ackermand D and Lal R K 1983 Regional geothermal-barometry in the granulite facies terrane of South India; Contrib. Mineral. Petrol. 73 221-244.

Raith M, Karmakar S and Brown M 1997 Ultra high temparature metamorphism and multi-stage decompressional of saphirrine granulite from the PalniHill ranges, southern India; J. Metamorph. Geol. 15 379-399. 
Replumaz A, Karasan H, Van der Hilst R D, Besse J and Tapponnier P 2004 4-D evolution of SE Asia's mantle from geological reconstructions and seismic tomography; Earth Planet. Sci. Lett. 221 103-115.

Rudnick R L 1995 Making continental crust; Nature $\mathbf{3 7 8}$ 571-578.

Rudnick R L and Fountain D M 1995 Nature and composition of the continental crust: A lower crustal perspective; Rev. Geophys. 33 267-309.

Rudnick R L and Gao S 2003 Composition of the continental crust; In: Treatise on Geochemistry 3 1-64.

Santosh M, Maruyama S and Sato K 2009 Anatomy of a Cambrian suture in Gondwana: Pacific-type orogeny in southern India?; Gondwana Res. 16 321-341.

Sarkar D, Chandrakala K, Padmavathi Devi P, Sridhar A R, Sain K and Reddy P R 2001 Crustal velocity structure of western Dharwar craton, south India; J. Geodyn. 31 $227-241$.

Sarkar D, Kumar M R, Saul J, Kind R, Raju P S, Chadha R K and Shukla A K 2003 A receiver function perspective of Dharwar craton (India) crustal structure; Geophys. J. Int. 154 205-211.

Savage B and Silver P G 2008 Evidence for a compositional boundary within the lithospheric mantle beneath the Kalahari craton from S receiver functions; Earth Planet. Sci. Lett. 272 600-609, doi: 10.1016/j.epsl.2008.05.026.

Spasojevic S, Gurnis M and Sutherland R 2010 Mantle upwellings above slab graveyards linked to the global geoid lows; Nature Geosci. 3 435-438, doi: 10.10308/ NGEO855.

Taylor P N, Moorbath S, Chadwick B, Ramakrishna M and Viswanatha M N 1984 Petrography, chemistry and isotropic ages of peninsular gneisses, Dharwar acid volcanic; Precamb. Res. 23 349-375.

Thompson D A, Bastow I D, Helffrich G, Kendall J M, Wookey J, Snyder D B and Eaton D W 2010 Precambrian crustal evolution: Seismic constraints from the Canadian Shield; Earth Planet. Sci. Lett. 297 655-666.

Thybo H and Perchuc E 1997 The seismic $8^{\circ}$ discontinuity and partial melting in continental mantle; Science $\mathbf{2 7 5}$ 1626-1629.

Tugume F, Nyblade A and Julia J 2012 Moho depths and Poisson's ratios of Precambrian crust in East Africa: Evidence for similarities in Archean and Proterozoic crustal structure; Earth Planet. Sci. Lett. 73-81 $355-366$.

van der Hilst R 2004 Changing views on the earth's deep mantle; Science 306 817-818.

van Kranendonk M J 2011 Onset of plate tectonics; Science 333 413-414.

White D J, Musacchio G, Helmstaedt H H, Harrap R M, Thurston P C, van der Velden A and Hall K 2003 Images of lower crustal oceanic slab: Direct evidence for tectonic accretion in the Archean western Superior province; Geology 31 997-1000.

Wessel P and Smith W H F 1998 New, improved version of the Generic Mapping Tools released; EOS Trans. AGU 79579 .

Wolbern I, Rumpker G, Link K and Sodoudi F 2012 Melt infiltration of the lower lithosphere beneath the Tanzania craton and the Albertine rift inferred from $\mathrm{S}$ receiver functions; Geochem. Geophys. Geosyst. 13 Q0AK08, doi: 10.1029/2012GC004167.

Zandt G and Ammon C J 1995 Continental crust composition constrained by measurements of crustal Poisson's ratio; Nature 374 152-154.

Zegers T and van Keken P E 2001 Middle Archean continent formation by crustal delamination; Geology 29(12) 1083-1086.

Zhu L and Kanamori H 2000 Moho depth variation in southern California from teleseismic receiver functions; J. Geophys. Res. 105 2969-2980. 